\title{
Artelogie
}

Recherche sur les arts, le patrimoine et la littérature de l'Amérique latine

2 | 2012

Mexique : espace urbain et résistances artistiques et littéraires face à la « ville générique »

\section{El Bordo de Xochiaca y la basura como naturaleza muerta: instalación colectiva y medio de resistencia estético-política en ejemplos de cine, fotografía y artes actuales}

\section{Elia Espinosa}

\section{OpenEdition}

\section{Journals}

Edición electrónica

URL: https://journals.openedition.org/artelogie/7966

DOI: 10.4000/artelogie.7966

ISSN: 2115-6395

Editor

Association ESCAL

Referencia electrónica

Elia Espinosa, «El Bordo de Xochiaca y la basura como naturaleza muerta: instalación colectiva y medio de resistencia estético-política en ejemplos de cine, fotografía y artes actuales», Artelogie [En línea], 2 | 2012, Publicado el 21 enero 2012, consultado el 07 enero 2022. URL: http:// journals.openedition.org/artelogie/7966 ; DOl: https://doi.org/10.4000/artelogie.7966

Este documento fue generado automáticamente el 7 enero 2022.

Association ESCAL 


\section{El Bordo de Xochiaca y la basura como naturaleza muerta: instalación colectiva y medio de resistencia estético-política en ejemplos de cine, fotografía y artes actuales}

\section{Elia Espinosa}

A Ida Rodríguez Prampolini y a los pepenadores ${ }^{1}$ del Bordo...

Así, de pie, con la nariz al viento llegan los signosmenos precisos pero más cargados de sentidos y sospechas, signos que quizá cuando tienes la nariz pegada al piso te niegas a recoger, te vuelveshacia otro lado, como ese olor que viene de las rocas delbarranco donde los de nuestra horda arrojamos a las bestias...y de allá, según sople el viento, sube junto con el hedor de los cadáveres... Italo Calvino, "Bajo el jaguar."

Para contextualizar el Bordo de Xochiaca, colosal vertedero en la Ciudad de México (Distrito Federal), es imprescindible mencionar que ésta es una urbe desmesurada, plena de energía que no sería exagerado calificar de "oceánica", en la cual, se libra, desarrolla y muere la vida cotidiana desarticulada, plural, de asimétrica armonía contrastante con las normas, la rutina urbana y la invención imaginativa, estructural y tecnológica, que de ella hacemos los individuos y grupos que la habitamos. Cual monstruo nos acoge y rechaza, nos incita y fatiga, transcurrimos en sus diversos 
territorios y zonas resolviendo necesidades, proyectando sueños... Por lo tanto, al aludir a ella, se hace referencia a la forma compleja y trágica en que lo político, lo ético, lo económico, lo estético, se compenetran en las consecuencias de la perversa y desigual brecha que existe entre poseedores de desbordados capitales y pobres que nunca saldrán del estado de desamparo en que se encuentran.

2 Esos vínculos que nos ligan a la Ciudad de México y sus áreas conurbadas, determinan las formas de vida de cada una de las zonas que la conforman, incluyendo la realidad de lucha, supervivencia, contradicciones y enigmas que se cruzan y determinan la administración de sus vertederos de desechos orgánicos e industriales de toda la ciudad, entre los cuales el Bordo de Xochiaca fue el más grande y antiguo. Ubicado desde hace sesenta y cinco años en la zona nororiente del Estado de México, municipio de Nezahualcóyotl-Chimalhuacán y cerrado para siempre desde el día 30 de noviembre de 2010, debido a una explosión causada por gases que se formaron en su subsuelo por las infiltraciones de fluídos de la basura orgánica, el Bordo permanecerá, con toda su potencia en la memoria colectiva de la ciudad.

Referirse a su estirpe es aludir a una zona de antigua tradición histórica y problemas urbanísticos pero, sobre todo, a un territorio estepario, una extensa mancha maloliente, un jardín bacteriano en donde se extienden y se elevan, en constante reciclaje múltiple, los millones de toneladas de deshechos del municipio mencionado y de áreas conurbadas del Distrito Federal. ${ }^{2}$

4 Ahí fueron volcados cadáveres de animales y de humanos (éstos, en otras épocas del siglo XX en México). Ahí fue a dar la mayor parte de lo usado, lo que "ya no sirve". Se configuró, así, un "retrato" informe de todos nosotros, tan íntimo y complejo como las formas de existencia que construimos en nuestras vidas reales y fantaseadas, al unísono con su autonomía simbólica arrolladora que manifiesta varias versiones de lo que ha llegado al final en reciclaje material e ideológico constante.

5 Esa autonomía del Bordo de Xochiaca depende, por supuesto, de cruces de fuerzas diversas: la de los pepenadores ${ }^{3}$, que durante más de cincuenta años, tras generaciones sucesivas, han separado la basura y subsisten de transformarla y venderla; la de los chavos banda ${ }^{4}$ nacidos en el lugar o que han emigrado a sus terrenos (figs. 1 y 2); la los "jefes de sección" que, al igual que en los Centros de Readaptación Social del Distrito Federal, controlan tanto el juego de poderes como la administración del lugar. 
Figura 1. "Bordo de Xochiaca", sección de composta fresca

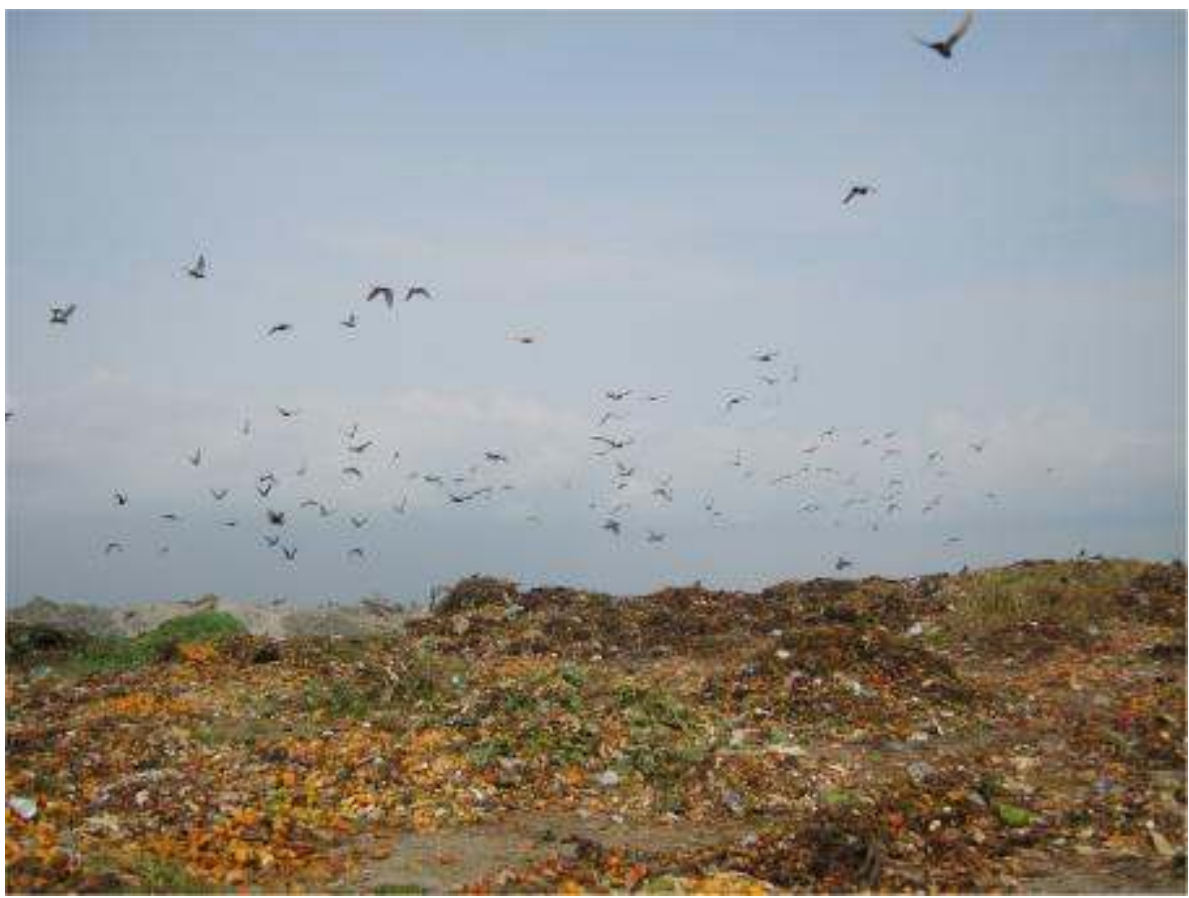

Foto Karla Hernández Lara

Figura 2. "Bordo de Xochiaca", sección de composta seca

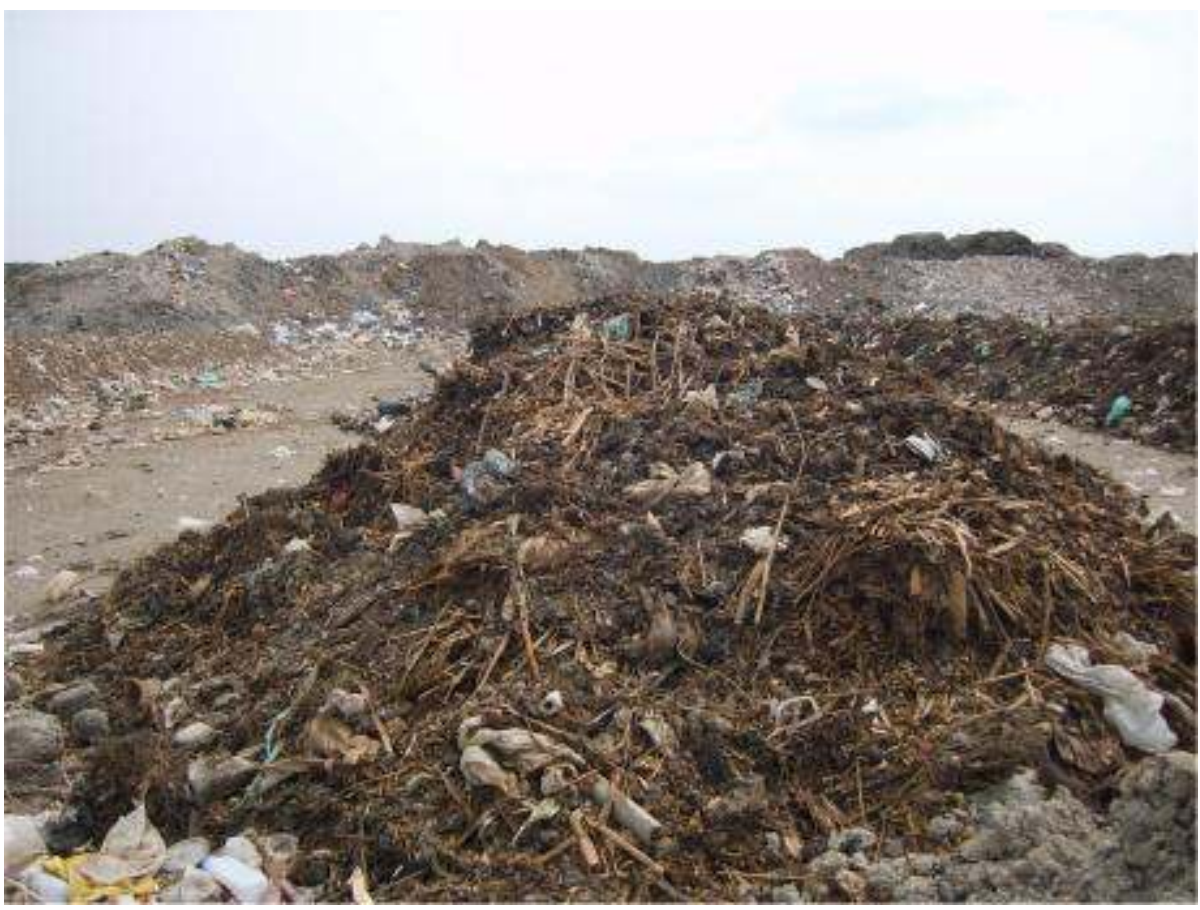

Foto Karla Hernández Lara

Dicho lo anterior, en este texto sustento el proceso de mi declaración del Bordo como derrocador y, a la vez, apropiador de la naturaleza muerta y la instalación en la historia del arte que construyo. Asimismo, busco ver la manera en la que ese tremendo 
vertedero fue, como símbolo trágico y universo basural, un recurso de resistencia estética y enriquecimiento de la significación en obras de algunos artistas.

\section{El Bordo derroca y se apropia de géneros visuales}

7 No es por azar que el medio de resistencia que fue y será el Bordo para algunos artistas, lo sea para la historia del arte en lo tocante a su antiguo y aún válido y funcional manejo de la naturaleza muerta, territorio del dominio de la pintura a lo largo de cuatro siglos y que en la actualidad sigue modos de composición de los siglos XVII al XIX, aunque su origen se remonta a los mosaicos pompeyanos. También son evidentes las variaciones experimentales que sufrió el género (la naturaleza muerta) a lo largo del siglo XX, lapso en que se convirtió en motivo y pretexto de interesantes obras cubistas, metafísicas y futuristas, figurando también en el cine intimista y poético de Andrei Tarkovski (1932-1986) ${ }^{5}$. Y si bien sigue cultivándose, ya no representa frutos, verduras, objetos de caza, misivas o largos pergaminos sino, en el caso del fotógrafo Joël-Peter Witkin (1939) ${ }^{6}$, bebés destazados, manos cortadas, pies putrefactos que se entreveran con aquellos elementos naturales que se trabajaron tradicionalmente en la naturaleza muerta (fig. 3). Asimismo, existe una vertiente de la fotografía que trabaja con la imagen compositiva tradicional de la naturaleza muerta, pero con frutos enlamados, con visibles fermentaciones, yendo más allá de sus "defectos" orgánico-visuales ${ }^{7}$ (como si hubiesen sido recogidos del Bordo). Es una estética de resistencia a una belleza impuesta por la historia del arte occidental.

Figura 3. Joël-Peter Witkin, "Naturaleza muerta con cadáver de niño"

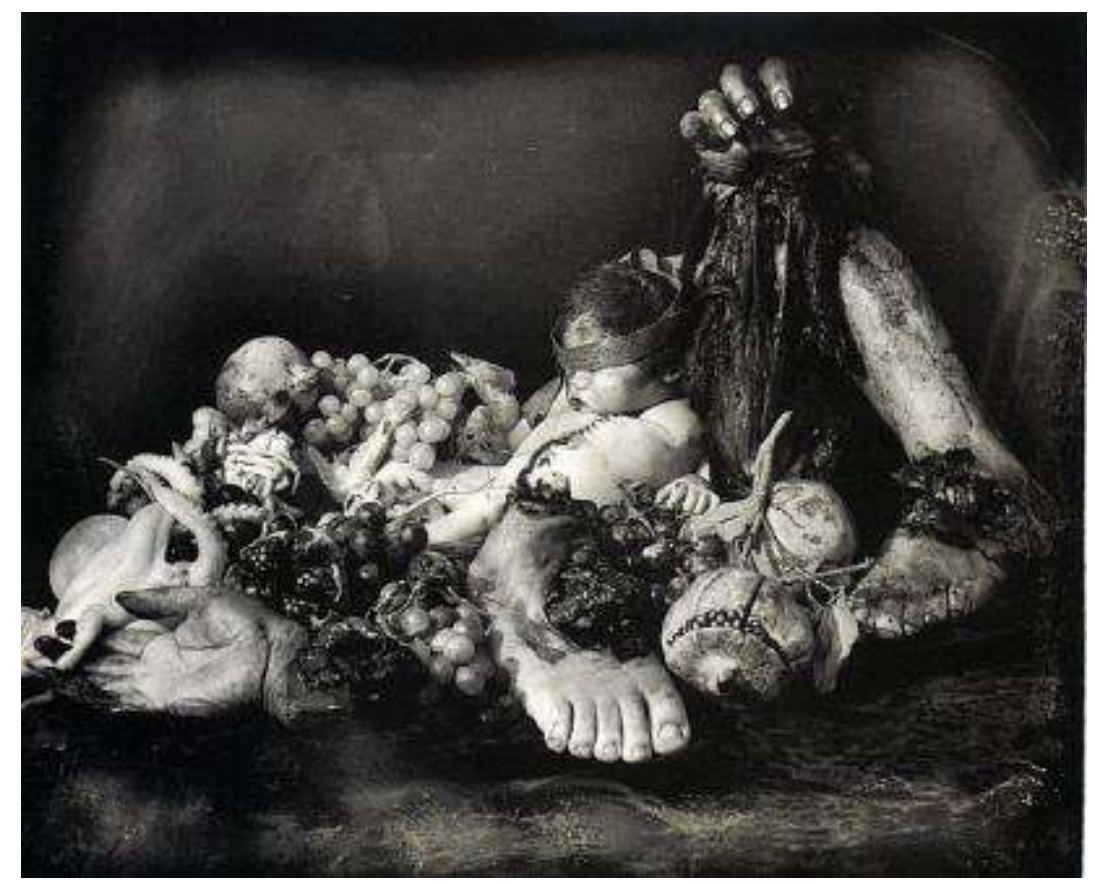

Las posturas de Witkin ponen la mesa para conjurar al Bordo de Xochiaca como una naturaleza muerta que contiene nuestros desechos y podredumbre, a la vez que toda la estirpe de una mega instalación urbana involuntaria que modifica el espacio generando la sensación de océano basural, estepa metafísica de desolado gregarismo, lugar de 
supervivencia de grupos que comercian con la basura, reflejan al sistema político social y son una especie de "para-imagen" de nuestra vida social.

9 Por lo tanto, llevada por una especie de necesidad epistemológica renovadora que parte tanto del proceso de la naturaleza muerta referido, como del impacto real que provoca en el espectador, torcí el brazo a la imagen del gran vertedero y al género de la naturaleza muerta para presentar a ésta como una antecesora de la instalación contemporánea que se desborda a sí misma, más allá del lienzo, teniendo la capacidad de recibir a la imagen del Bordo para resignificarse a sí misma por la intersección del gran vertedero; sí, el Bordo es práctica y socialmente mayor en impacto vivo, contundencia visual y aromática que cualquier naturaleza muerta pintada, ya que posee una fuerza sublime que nos enlaza súbitamente con una sensación de infinitas germinaciones que alimentan una estética escatológica innegable. (figs. 4 y 5).

Figura 4. "Bordo de Xochiaca", sección de objetos generales

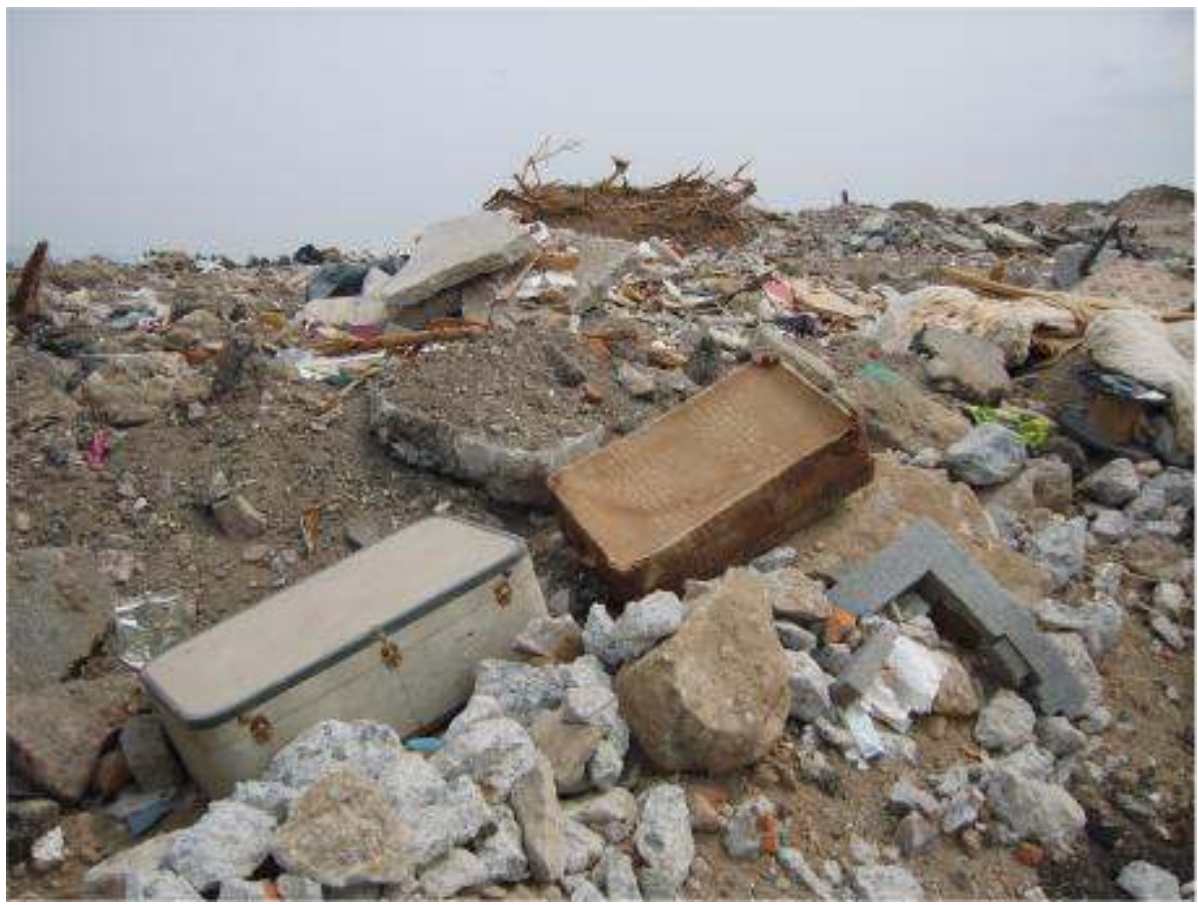

Foto Karla Hernández Lara 


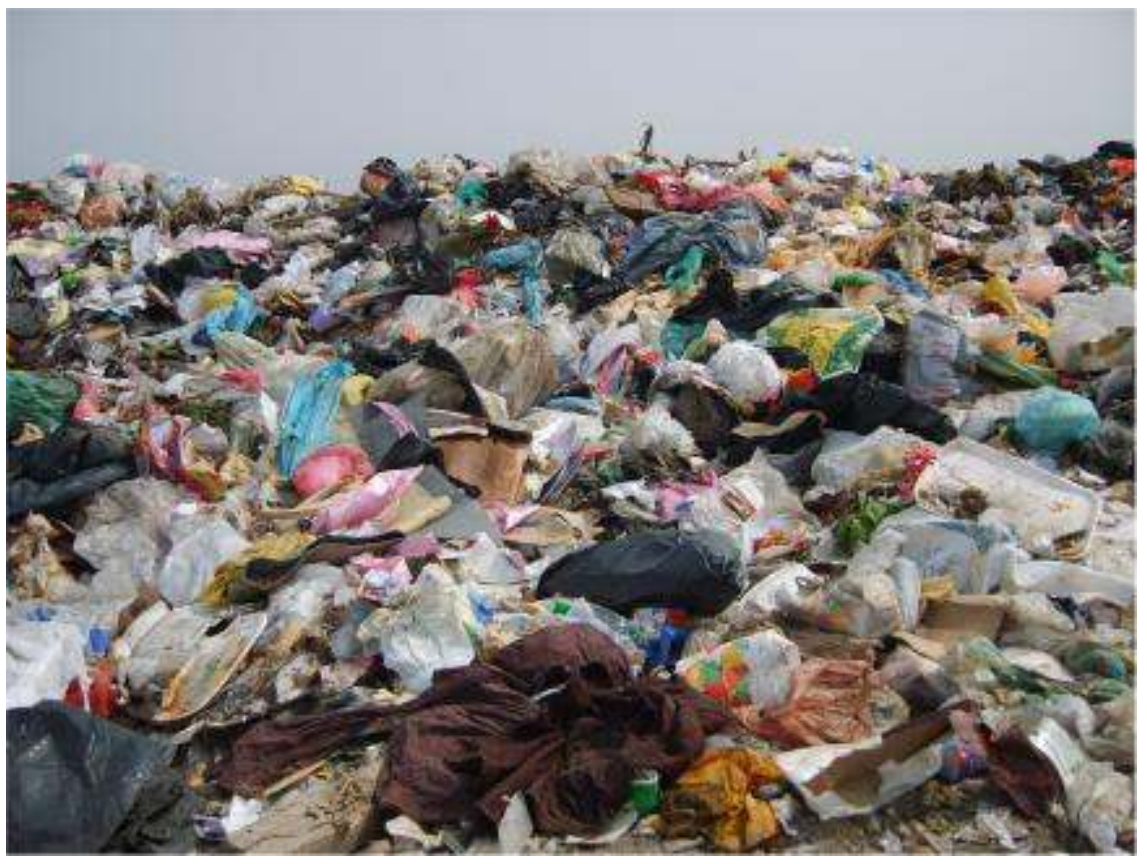

Foto Karla Hernández Lara

La presencia de la naturaleza muerta en los museos encuentra súbitamente un eco vivaz en la imagen múltiple, orgánica, industrial y humana del Bordo. Éste se transmuta en la más grande naturaleza muerta-instalación viviente en el Distrito Federal y sus áreas conurbadas como panorama integrado a nuestro horizonte. Vertedero pródigo en formas de vida y de percepción para acercarnos a su imagen como combinación de lo inerte y lo vivo, orgánica e inorgánicamente, el Bordo de Xochiaca se convierte en un recurso sinestésico que, por medio de la obra de varios artistas, cuestiona una historia del arte tradicional que consideraría solamente la imagen de la "obra artística" como válida. El Bordo, dentro de este contexto, extiende el campo de conocimiento de esta disciplina ya que ese vertedero pródigo ofrece una infinidad de posibilidades de percepción y la relaciona para siempre con una fuerte política de la imagen.

De poderosa energía resignificadora y resimbolizadora de la vida ciudadana, el vertedero ha ocupado a varios cineastas, fotógrafos, artistas de artes de acción independientes, mexicanos y extranjeros en la elaboración de su obra. Les ha impactado y a la vez intimidado su gigantesca realidad que exige el vuelco del mundo íntimo hacia afuera, en una especie de juego de espejos, inabarcable con los ojos, más recurso metafísico intensificador de la significación de sus obras.

Un objeto puede transformar sus posibilidades de significación múltiple, según un contexto determinado. No es lo mismo declarar al Bordo una instalación gigantesca desde y para la historia del arte como construcción de narrativas que sufre así benéficas fracturas epistemológicas, que como elemento que coadyuva en el refuerzo del sentido trágico de una circunstancia y que, por lo mismo, puede ser un medio de resistencia. Ese manejo ha fructificado plenamente en el cine, la fotografía y las artes no objetuales. 


\section{Como resistencia en el cine}

13 Las obras experimentales de Alfredo Joskowickz (México, 1939), Leobardo López (México, 1942-México, 1970), Sarah Minter (1953) y de cineastas de generaciones más recientes, como Rogelio Martínez Merling y Gabriela Santos del Olmo (1977), están indisolublemente impregnadas del movimiento estudiantil del 68. Desde diferentes posturas y distancias, surgen recuerdos, se perciben las consecuencias libertarias (mucho más en la intimidad individual que a nivel social) y la complejización de la dinámica social en México a partir de aquel acontecimiento socio-político, cuyos resultados se unen hoy a los embates de la globalización. No obstante las diferencias entre esos cineastas, confluyen en sus apropiaciones y reutilizaciones simbólicas de la imagen múltiple del Bordo.

14 Una de las prospectivas futurizantes del 68 es que la cultura urbana, viva y politizada en el sentido de ser una constante escenificación de lo ético, existió y existe en lo que atañe a una conciencia de las energías de lo acontecimental posible. Así lo muestran las acciones contundentes, las nuevas escalas de valores en lo moral, lo metodológico o lo proveniente de un reciclaje del pasado cultural remoto, resuelto en el aquí y ahora de pobreza y muerte que determina a no pocas zonas de la Ciudad de México y del país en la actualidad.

15 El cine, a la luz del Bordo, volverá visibles no pocos problemas sociales. Crates, de Alfredo Joskowickz, largometraje filmado en 1970, denota a un contundente cineasta de expresión, lejano del cine industrial y comercial. Su película está impregnada del margen de acción libertario y el aliento trágico del México postsesenta y ocho, que aún mueve la resaca de las revueltas estudiantiles. En una secuencia de Crates, un Bordo de Xochiaca de hace cuarenta años, parcialmente libre de las toneladas de basura que acumulará a lo largo de varias décadas hasta su cierre definitivo, respalda y acoge el cambio radical de vida que decide el protagonista ${ }^{8}$. A la manera del filósofo cínico griego, quien renunciara a sus pertenencias regalándolas a sus amigos para dedicarse a errar y vivir de lo que el filo de los días le diese, un Crates contemporáneo compartirá sus días y objetos básicos (lo que trae puesto y un morral) con mendigos, pepenadores y animales hambrientos, haciendo de la naturaleza y la basura un sustento. (Fig. 6).

Figura 6. "Crates", Uno de sus amigos rechazando su ofrecimiento de dinero

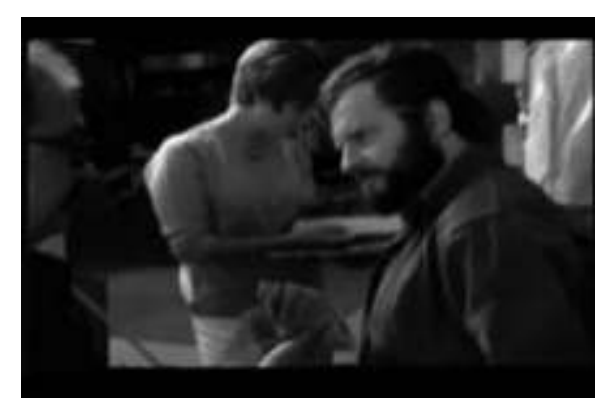

Personaje extremo en sus decisiones, Crates busca una esencia espiritual y material. El Bordo de Xochiaca se vuelve "su" escenario, por el sesgo trágico-libertario de una existencia decidida a resolverse paso a paso a partir de la escala de saberes prácticos y morales de la pobreza ${ }^{9}$. También palpita la pérdida de sí mismo, el movimiento incesante que se traduce en acciones que recuerdan el fuerte aliento de un hippismo de pátina 
franciscano-cristiana que, sin embargo, no impide la caída: el grito en el que estallará el protagonista. Una mezcla de fin último y traza de nuevos caminos caracterizan la gravedad de Crates, hombre que encontrará otra esperanza y renovación en el amor con una mendiga que va a buscarlo al Bordo (uno de los personajes en el inicio de la película, cuando está regalando sus pertenencias), con quien tiene un hijo. Es obvio el rescate de un mundo espiritual, de talante bíblico, y la traza de un Camino que llevan a cabo Joskowickz-Crates. (figs, 7 y 8 )

Figura 7. "Crates" en la estepa del Bordo

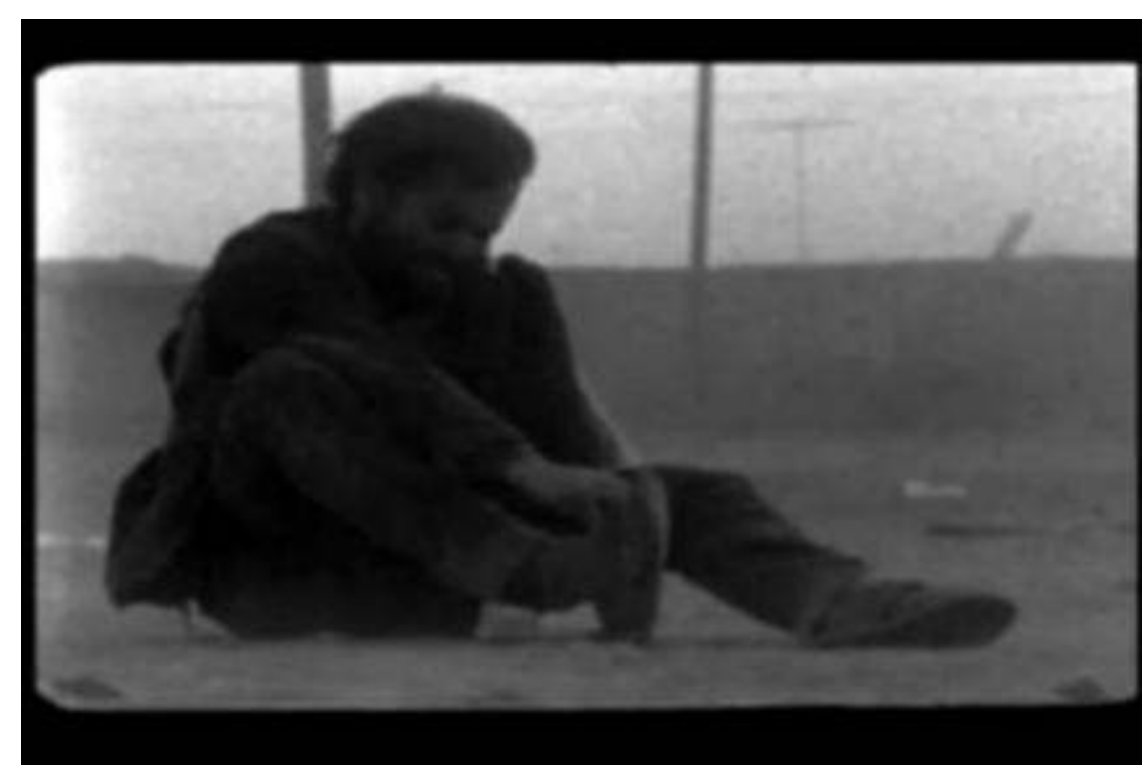

Figura 8. "Crates"...el grito

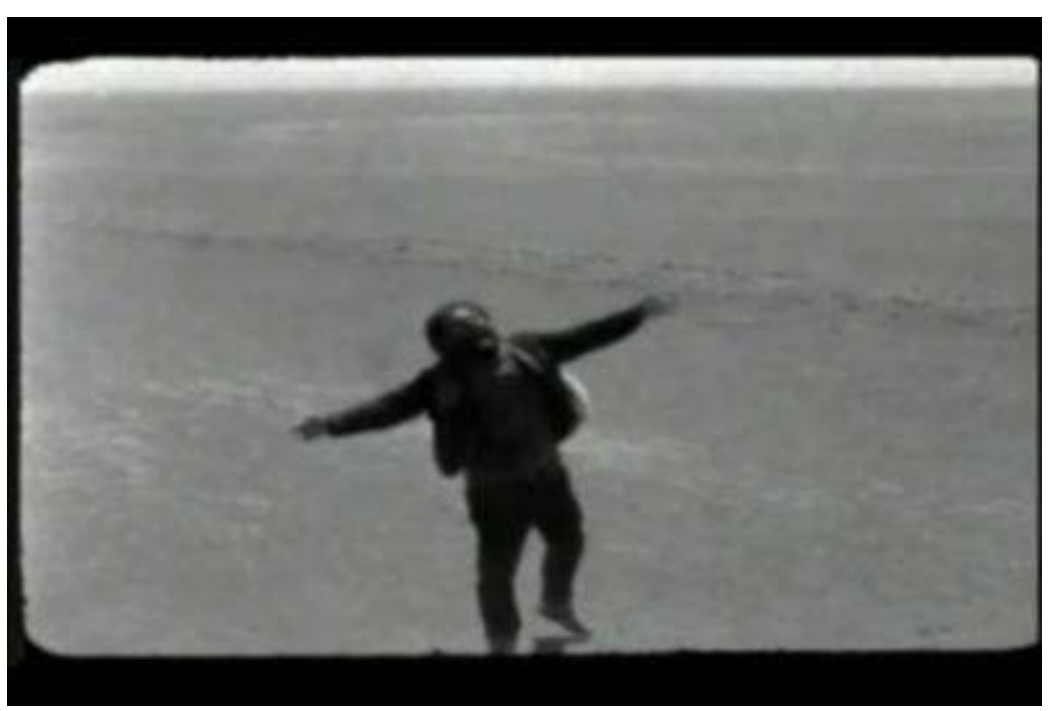

El grito al sentido estepario de la existencia, es decir, a la vida como aventura dramática resuelta profundamente desde la soledad, la esperanza ético-política nacida del respeto y del trato digno de sí mismo y del otro, de los otros, al mismo tiempo que una fidelidad al esplendor del deseo y no al Sistema, sin perder de vista el camino de sencillez y universalidad que propone el filme Crates, se emparentan con el cortometraje Habitáculos (1999), de Gabriela Santos del Olmo. 
Esa joven cineasta inserta en su obra temas e imágenes del Bordo de Xochiaca por el lado de los terrenos en donde se erigía una antigua fábrica de sosa (hoy inexistente) y un reclusorio próximo a ese lugar, ámbitos en los que una muchacha, la protagonista, experimenta el desencanto de la pérdida, el abandono, la soledad. Halla refugio, no obstante, en esa apertura a cielo abierto después de la ruptura con su amante, un suicida en potencia (figs. 9 y 10) cuyas indecisiones propician que la protagonista se involucre pasionalmente con un camionero maduro. El Bordo aparecerá brevemente, al tiempo en que ella camina hacia una antigua capilla abierta construida de lámina, hoy derribada.

Figura 9. "Habitáculos", el suicida

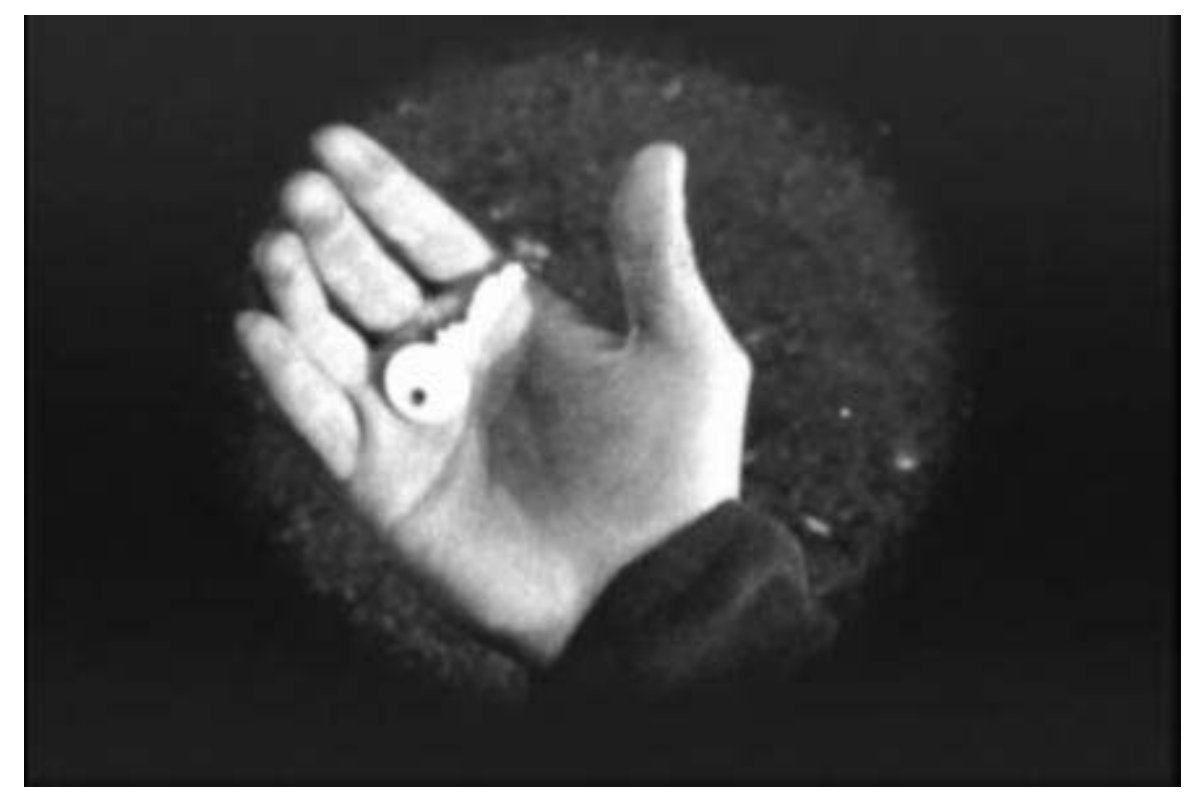

Figura 10. "Habitáculos", el suicida

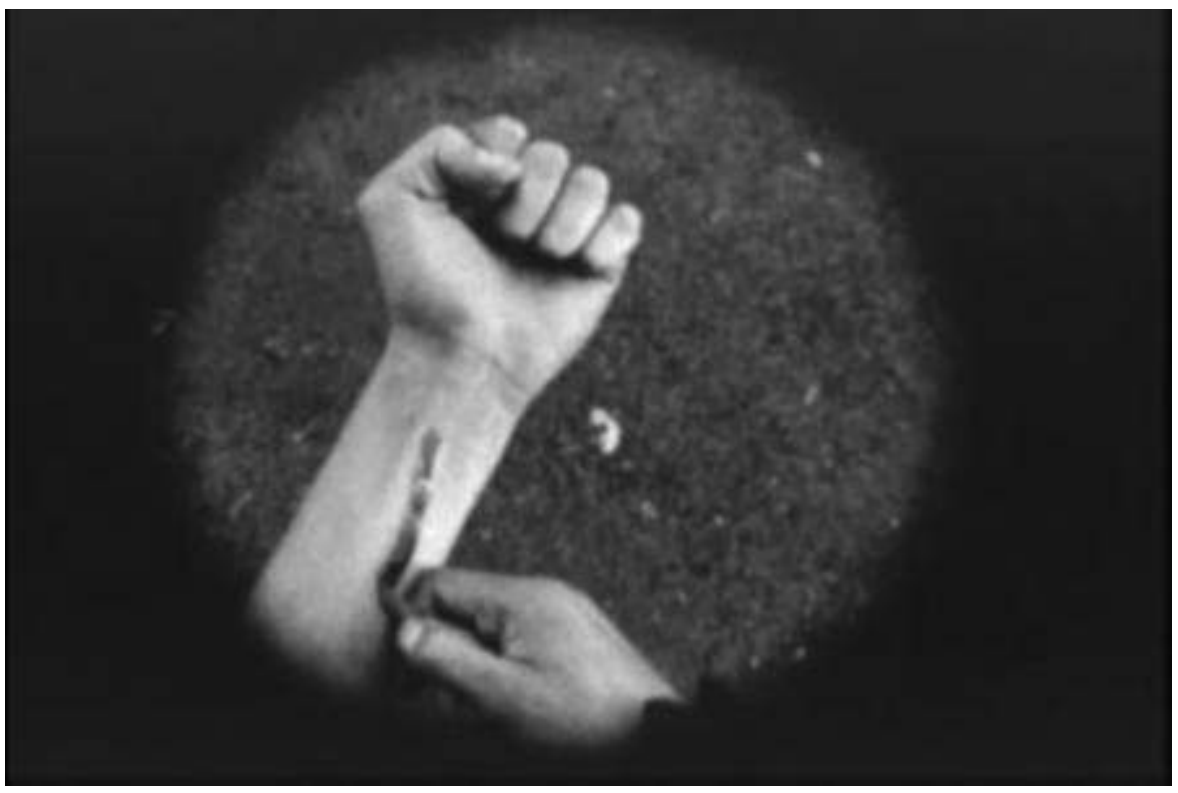


Allí se sienta y contempla los adornos de plástico picado y las figuras sagradas que pueblan el espacio. Con la antigua técnica del enfoque en círculo que se cierra hasta desaparecer, propia del cine expresionista alemán y norteamericano mudos, Gabriela Santos enfoca los hombros y rostro de la actriz, luego el reclusorio y, por último, hace una brevísima toma de láminas de asbesto y un bote, diciéndose a sí misma en silencio: "huele bien sabroso", expresión que aparece en letras blancas sobre fondo negro (fig. 11).

Figura 11. "Habitáculos", barracas y restos inorgánicos en el Bordo de Xochiaca

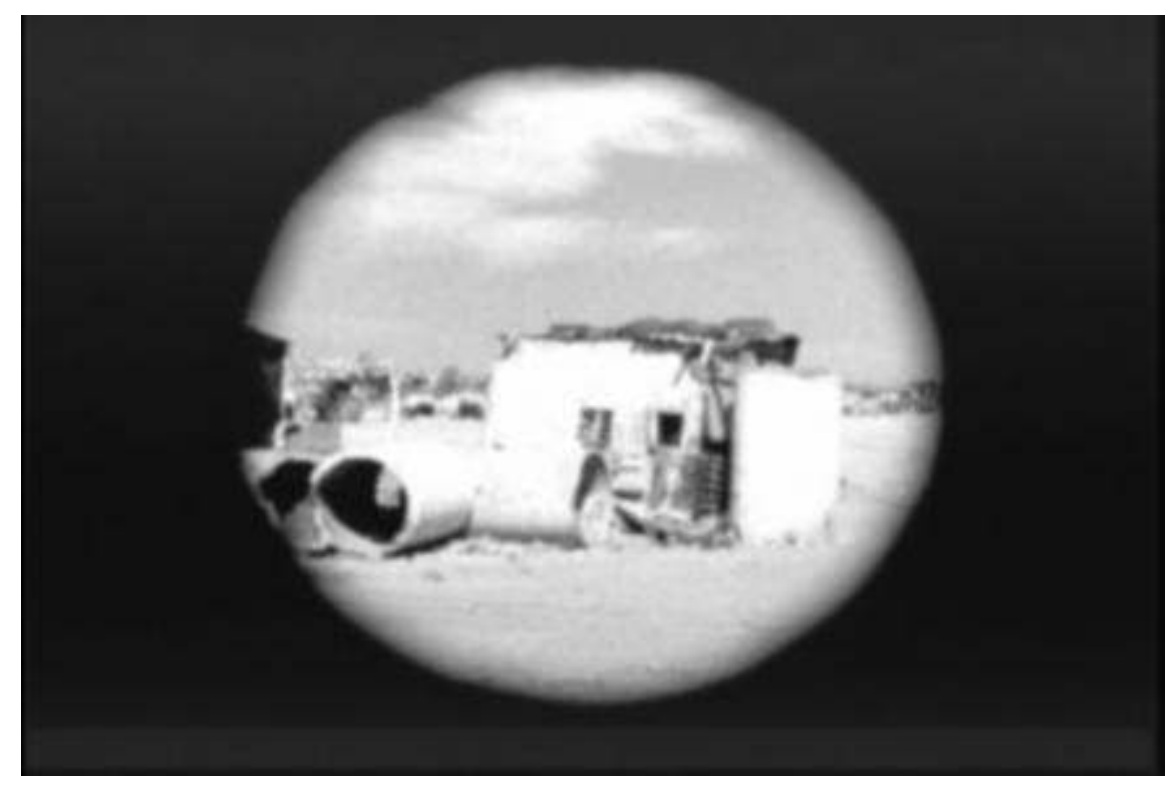

Desde el inicio de la cinta, Gabriela Santos cimenta el orden estético del cortometraje con base en tomas de monumentos y edificios cuyo orden rectilíneo contrasta con lo caótico de los sentimientos y emociones que expresan las imágenes en su conducción del sentido de inmanencia que le dicta el propio curso de la grabación, impregnada, por cierto, de un hilo de improvisación. La obra termina cuando, con un impulso de esperanza, la protagonista sale del Bordo, se queda viendo un partido de futbol y luego va hacia la carretera.

21 Sarah Minter y Rogelio Martínez Merling incorporan el Bordo de Xochiaca de formas diferentes. Mientras Minter lo hace ver en el cortometraje intitulado Nadie es inocente (1987), Martínez Merling filma el documental Pepenadores (1992) tal cual era el Bordo en esa época, siguiendo día y noche, sin cesar, las actividades de los habitantes del gran vertedero. Nadie es inocente se centra en el adiós a Ciudad Neza de un "chavo banda". Se despide concibiéndola como lugar de locura, desafíos y soluciones audaces de la vida que, desde su monólogo, recuerda a los taimados de José Guadalupe Posada ${ }^{10}$, seres de empoderado valemadrismo ${ }^{11}$. El Bordo pasa ante nuestra mirada como el cierre de una estadía, un albergue común abandonado para poder trazar una línea de fuga propia, una línea deseante cuyo origen es el hartazgo. Más que huída, la determinación del joven de menos de veinte años, un verdadero bordoxochiaquense, no se origina por ir a la busca de ningún "objetivo" (postura moderna), sino en seguir involucrado en la resolución de la vida como un reto que, aún en la dureza y la dificultad, le propician un gran disfrute. En Nadie es inocente, el Bordo es el receptáculo de la vida y de la muerte de 
los ciclos subjetivo-emocionales y mentales del joven sujeto, proceso respaldado por una cultura de valores extremos.

El cortometraje Pepenadores, del cineasta Martínez Merling. es un documental armado a partir de la urgencia de hacernos partícipes de la experiencia y los saberes del Bordo, del reconocimiento y la afectuosa paciencia de un director y un equipo que, material y espiritualmente, se embarcan en el acontecer del lugar. Su autor no escatimó cinta para filmar las costumbres y maneras de supervivencia cotidiana de los pepenadores y otros habitantes "satelitales" de sus extensiones. Seguramente, el documental fue realizado con motivo de uno de los intentos fallidos de cierre definitivo que sufrío el Bordo durante los últimos quince años.

El cortometraje de Martínez Merling confirma que el Bordo de Xochiaca siempre se vio como una zona que se debate entre ser y no ser, entre su exuberancia y su hedor; zona en donde algo termina y está por venir otra cosa, otra fantasía que se transforma. De ahí que la pieza cinematográfica guarde la filmación de los antiguos camiones recolectores de basura de los años ochenta y noventa, las cascadas de desperdicios, los mares de papel limpio, cortado en tiritas, en donde juegan a sumergirse, como en espuma, los hijos pequeños de los pepenadores; los trabajadores que expusieron al cineasta, de noche, sus quejas políticas, sus cuestionamientos al incumplimiento de los políticos que no les han cumplido sus promesas. Contiene también la grabación de una fiesta de quince años en la que un cura bendice a dos quinceañeras y alaba especialmente que los pobres gasten el dinero en compartir momentos con sus seres amados y no en la adquisición de cosas materiales, secuencia que representa uno de los grandes momentos ideológica y visualmente complejos en el filme. Pepenadores exhibe un Bordo autónomo, hito simbólico de la vida y la muerte, único en la ciudad; umbral apocalíptico que Martínez Merling acentúa en las imágenes finales en donde el basurero gigantesco aparece con la faz de un mundo posterior a la explosión de una bomba que arrasara con todo (figs. 12 a 15).

Figura 12. "Pepenadores", revolvedora

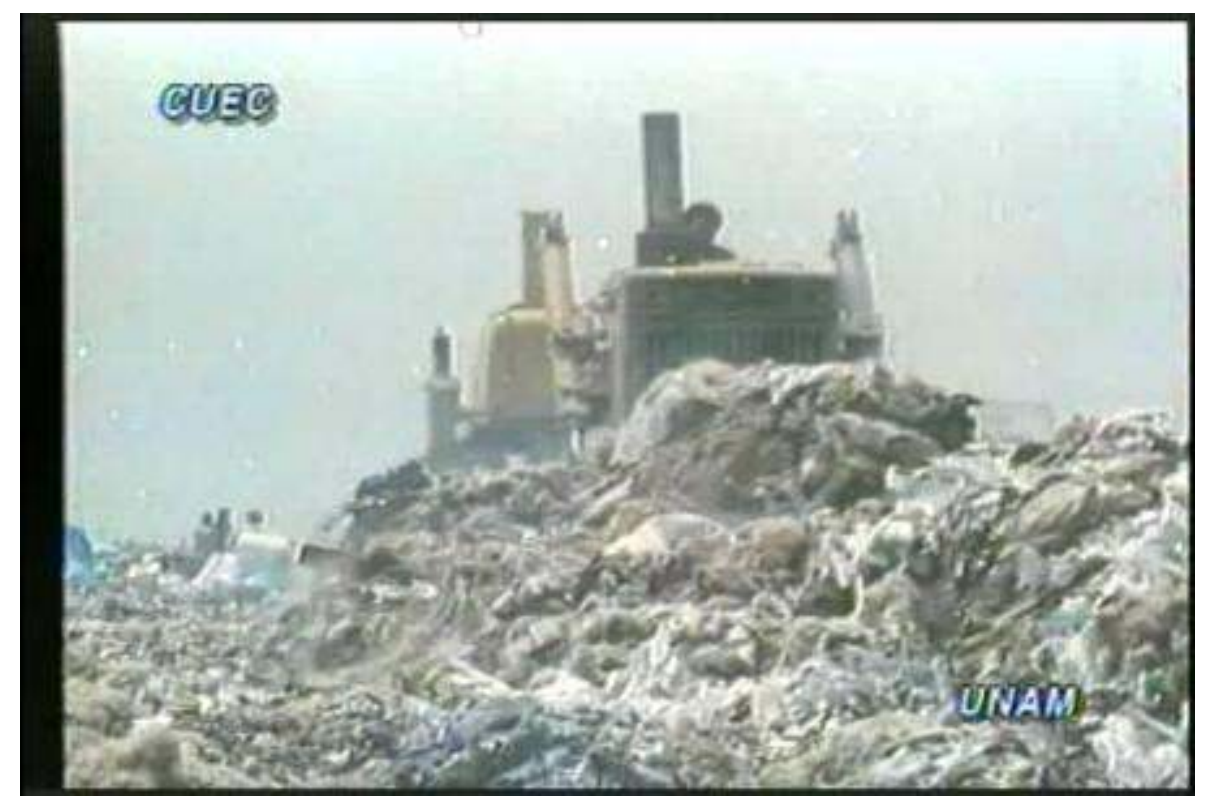


Figura13. "Pepenadores", la quinceañera hacia la capilla

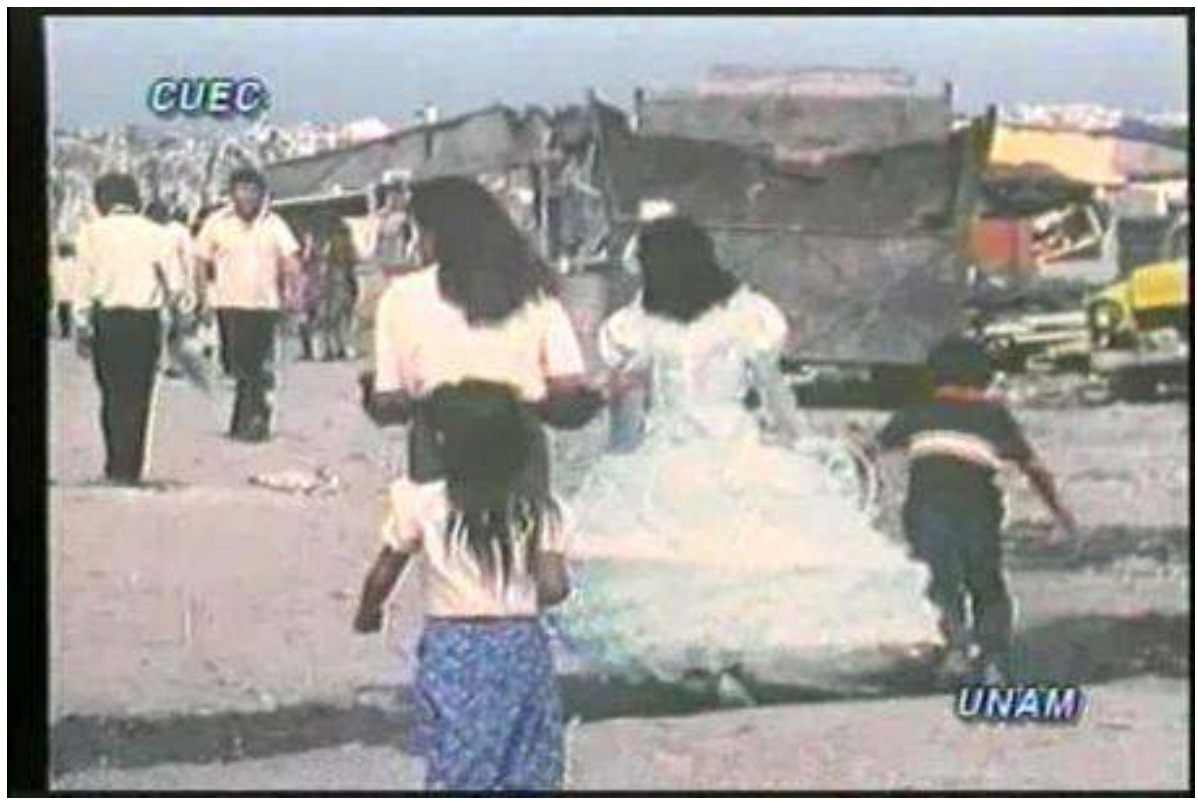

Figura 14. "Pepenadores", barraca y botes

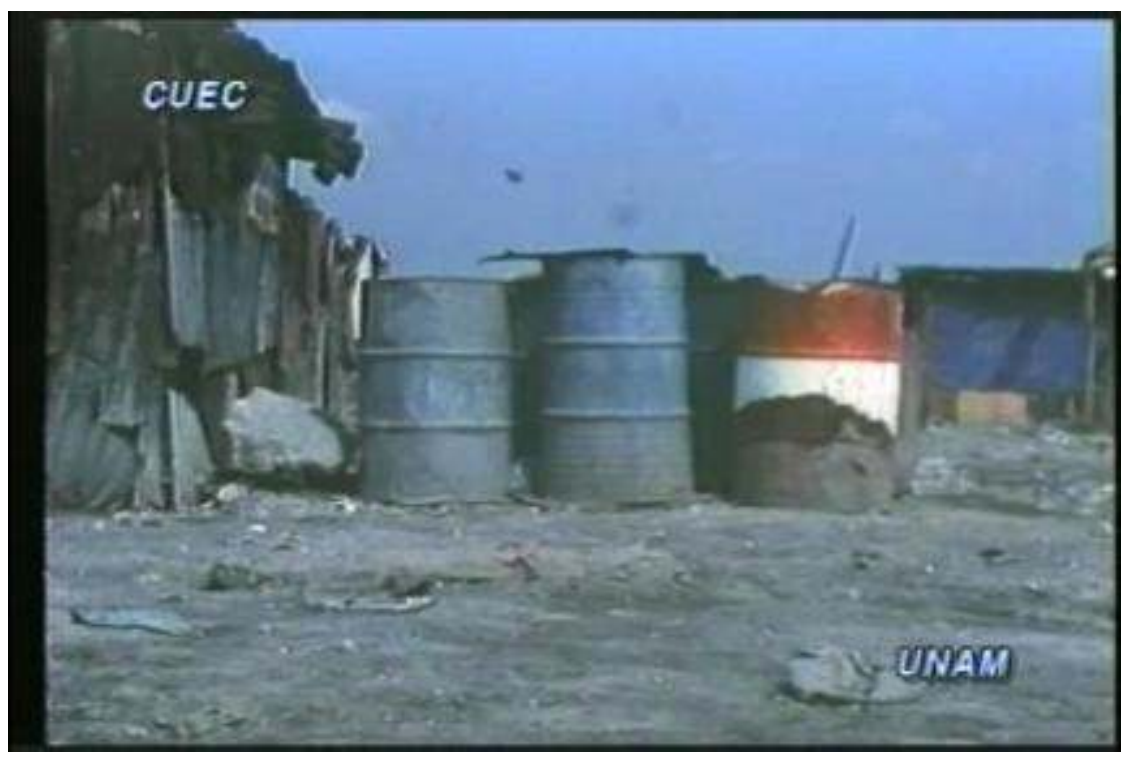


Figura 15. "Pepenadores", ¿el fin del mundo ?...

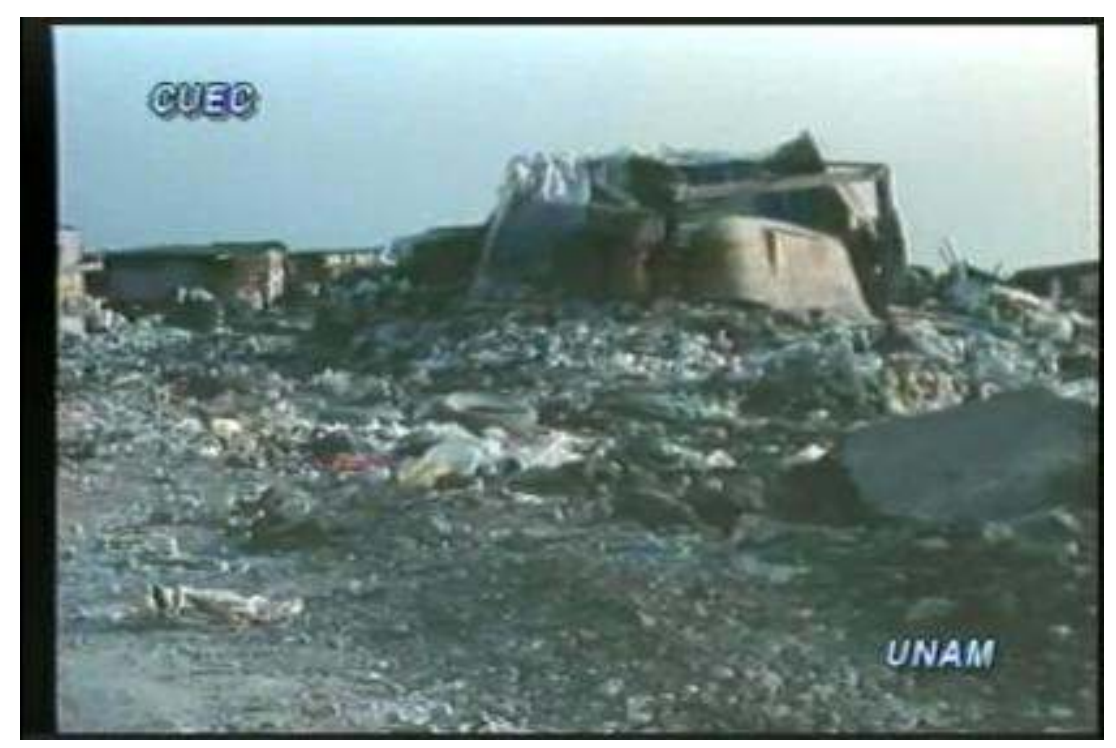

\section{La basura en la obra de un fotógrafo y seis instaladores y performers}

Imposible no subrayar el hecho de qué tan fuerte ha sido el trabajo colectivo con el que todos contribuimos en el pasado a la hechura de la gran naturaleza muerta-instalación que es el Bordo de Xochiaca, como la especie de trabajo con basura a pequeña escala que han construído artistas mexicanos y extranjeros en las instalaciones y performance-instalaciónes que han trabajado con su aparición. Así, no es posible prescindir del potencial de la basura como materia y como imagen ni, en cuanto a la historia del arte se refiere, mencionar la valoración que el neodadá y el pop hicieron de la basura como producto humano que nos da idea del lado miserable y de las dimensiones de producción y consumo en las urbes.

Lo basural y los reciclajes materiales enlazados al señalamiento de problemas ecosociales y políticos, nos llevan a elaborar estéticas diversas y están presentes en decisivas propuestas contemporáneas, en la metáfora y la imaginada realidad que fuera en lo político artístico el ya mencionado movimiento estudiantil del 68. Es decir, quien asesina a un individuo o a un grupo, crea súbitos vertederos metafísicos que sugieren toda una dimensión virtual tanática. A decir de Juan García Ponce, en "Problemas de memoria": "Una matanza convierte cualquier lugar en un basurero. Los sucesos cuyo carácter público deben permitir su comparación objetiva y su permanencia en el tiempo, se alejan con mayor velocidad que cualquier otro. Su signo es la negación de sí mismos"12.

El movimiento del 68 fortaleció el criterio político-social. El arte que se elaboró al compás de su desenvolvimiento, opositor de lo individual en pro de lo grupal sin menoscabo de la obra de autor, propició su crecimiento en la globalización, dimensión en donde es bienvenida la aportación tanto de colectivos como de individuos. La lucha contra el Poder se ejerce en los ámbitos del mainstream y/o en la creación de centros de acción en los sistemas de vida mundiales por medio del potencial estético de la obra. 
Tales combates no se libran en forma de protesta o transgresión sino actuando desde el interior de los sistemas.

Una de las posturas más críticas y refinadas de la segunda mitad del siglo XX en México y en el mundo, fue proporcionada por los conceptualismos. Tras el "cansancio" de la investigación artística y del arte objetual, (la "obra de arte" museal), así como el surgimiento del performance ya contemplado como un modo específico en el arte, se hace necesario inducir al espectador a crear una zona de percepción-reelaboración conceptual que comparte el artista mismo. Lo importante para éste es, en última instancia, el plano metafísico de reelaboración mental y emocional que hará el espectador ante la relación de elementos que se combinan y resuelven en la obra (papel, vacíos espaciales, basura, color, palabras) para que emerjan la ambigüedad y la ambivalencia sugerentes, la minimización de recursos. De esa manera, investidas de conciencia, azar y agudeza crítica, se han producido obras que en su pasión experimental y estructural han tenido el fin de rescatar un sentido crítico e intenso, o recurrir a la contemplación que crea una silenciosa resistencia en el marco de una admirable poética de revaloración del espacio como un in extenso, continente y génesis de sentido en la extensión urbana y ciudadana.

La fotografía del Bordo de Xochiaca que tomara en 2002 el fotógrafo alemán Andreas Gursky (1955), interesante experimentador visual que tomó al vertedero como una estepa infinita (fig. 16), paisaje sin seres humanos, es un documento visual en donde la basura ya ha sido separada o seleccionada y aparece esparcida por el viento. No sorprende que Gursky se ocupara de esa imagen cuyo apacible orden caótico es evidente y contrasta con otras obras suyas en donde priva el orden concéntricoexcéntrico (modo aprendido de su maestro Berndt Becher) de tomas aéreas de la Bolsa de Nueva York (fig. 17), o de un nudo de tránsito en El Cairo. En la primera, crea áreas de color que bien pueden compararse con su fotografía del Bordo en algo que yo llamaría una "composición vibrante", y en la segunda, dispone los vehículos en orden asimétrico (fig. 18).

Figura 16. Andreas Gursky , "El bordo estepario"

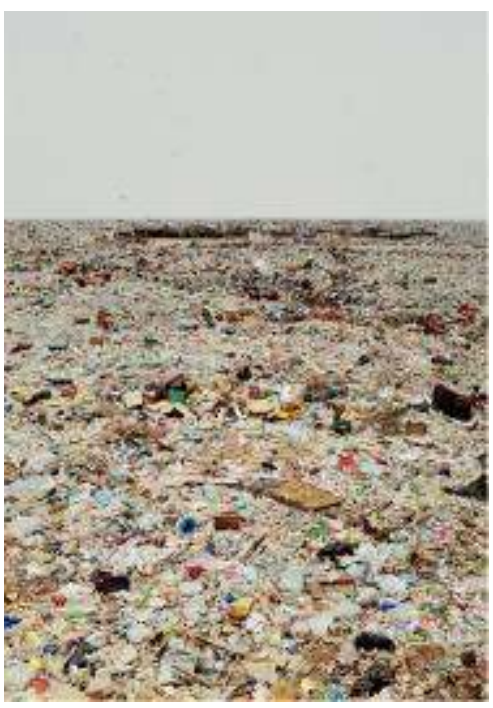


Figura 17. Andreas Gursky, "Bolsa de Nueva York"

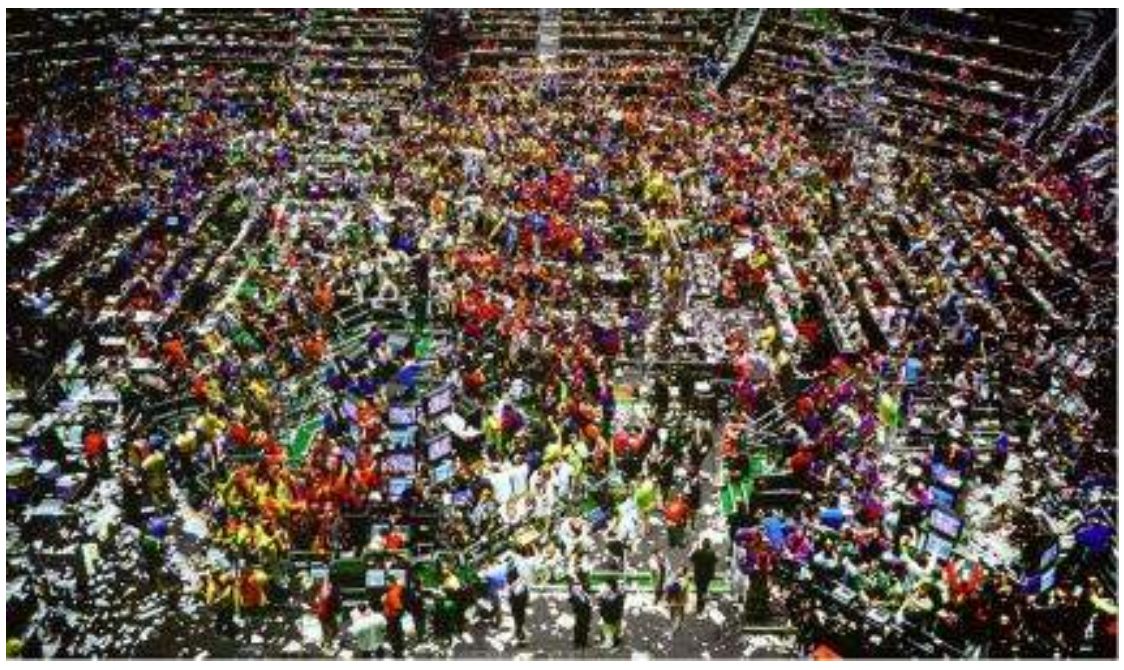

Figura 18. Andreas Gursky, "El Cairo"

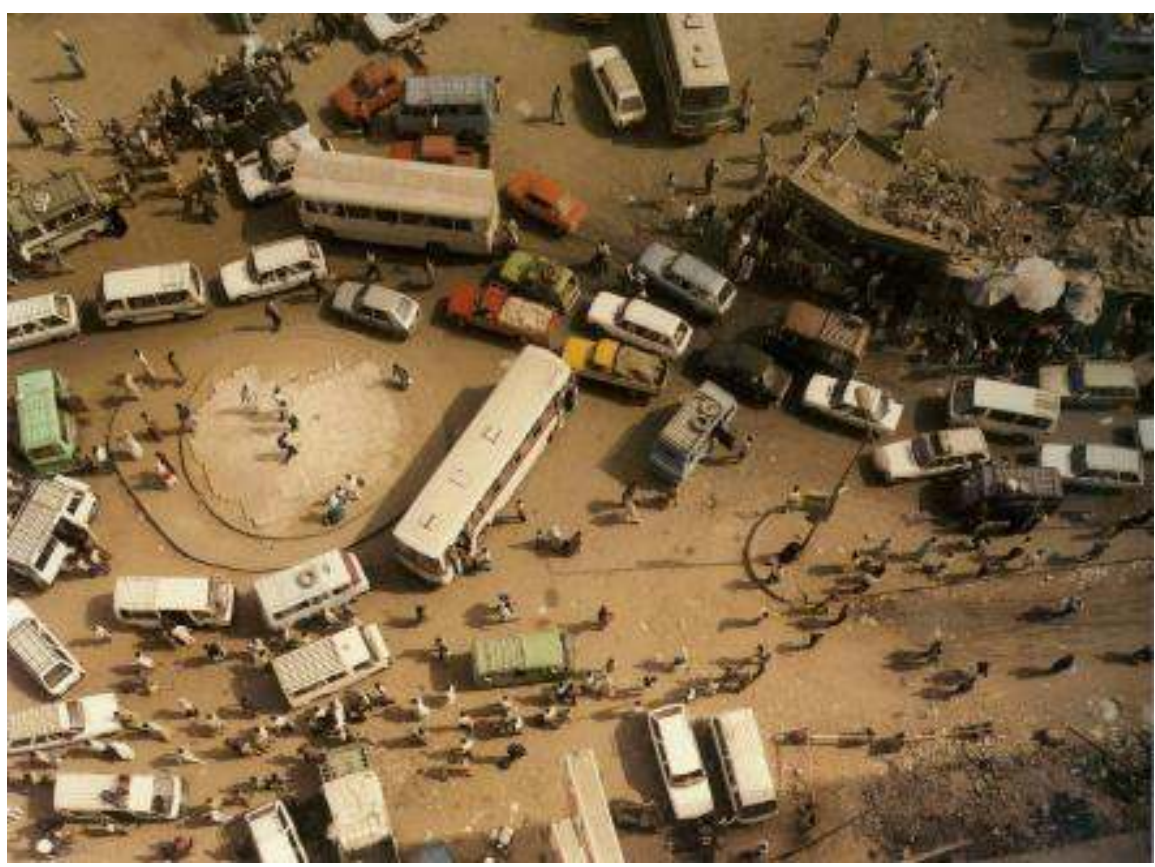

Gursky posee una destreza para lograr conglomerados cromáticos que van más allá de los objetos reales fotografiados en sus apretados conjuntos, tendencia igualmente visible en su pintura y en sus instalaciones.

La norteamericana Donna Conlon (1966) integra basura tecnológica a la naturaleza y ella misma considera su trabajo como un cuestionamiento socioarqueológico en mi entorno inmediato. Revela ángulos íntimos, contradicciones de la naturaleza humana en su cotidianidad contemporánea. En el tipo de basura que reúne en sus instalaciones descubrimos la presencia de botellas de plástico (pep), restos tecnológicos e, incluso, colillas de cigarro. Se trata de un arte de sumo contraste y, al mismo tiempo, compenetración de química sintética cargada de una simbolización proveniente de fenómenos naturales en movimiento, tales como un río, un arroyo, o caminos que la costumbre labra: por ejemplo el atajo o camino rectilíneo que el paso de ida y vuelta de 
los caminantes va construyendo en los parques y bosques con el fin de evadir el sendero curvo que alargaría su llegada al punto deseado.

31 En su muy especial poética de la deriva, Francis Alÿs (Belgica, 1959) interviene y se apropia de la naturaleza en la urbe. Sorprenden, por su inventiva, los objetos maquinales-conceptuales destinados a ser rodados cual carritos de niño, así como su registro de la acción de barrenderos empujando, a un tiempo y ritmo colectivo, una tonelada, por lo menos, de botellas de plástico en el centro del Distrito Federal. Alÿs es un artista cuya comprensión del dúo acción/azar y el recorrido aleatorio en el que el objeto es seguido hasta culminar en su desaparición, o en la puesta en riesgo extremo del propio cuerpo del artista, son recursos fundamentales. Recuérdese la acción en la que empuja un bloque de hielo hasta que se deshace. 0 aquélla otra en que un taxi lo atropelló en el Zócalo por perseguir, absorto, una botella de plástico vacía movida por el viento.

32 Felipe Ehrenberg (1943) y Víctor Muñoz (1948), integrantes, entre otros, del Grupo Proceso Pentágono que se constituyera a principios de los años setenta, y artistas de sobresaliente despliegue conceptual e innovador en lo tocante a los dispositivos o medios de trabajo, también han incluído basura industrializada en sus instalaciones. En los performances de Ehrenberg, como el de Londres en el 2007, la basura es útil para recordar su contundente presencia en la urbe (fig. 19). Muñoz es proclive a una interiorización trágica del sentido de la fuerza simbólica de la vida social y de la sombra del Poder sobre ella o al trabajo desde un intimismo muy sutil. Sus instalaciones son contundentes por el equilibrio entre signos y mensaje, como aquélla construída con una herrumbrada y antigua camioneta Renault 14, que perteneció a una pareja cuyas pequeñas fotos en óvalo aparecen triste y melancólicamente adheridas a los vidrios laterales delanteros del vehículo situado sobre un montículo de arena. (fig. 20).

Figura 19. Felipe Ehrenberg, Performance con basura

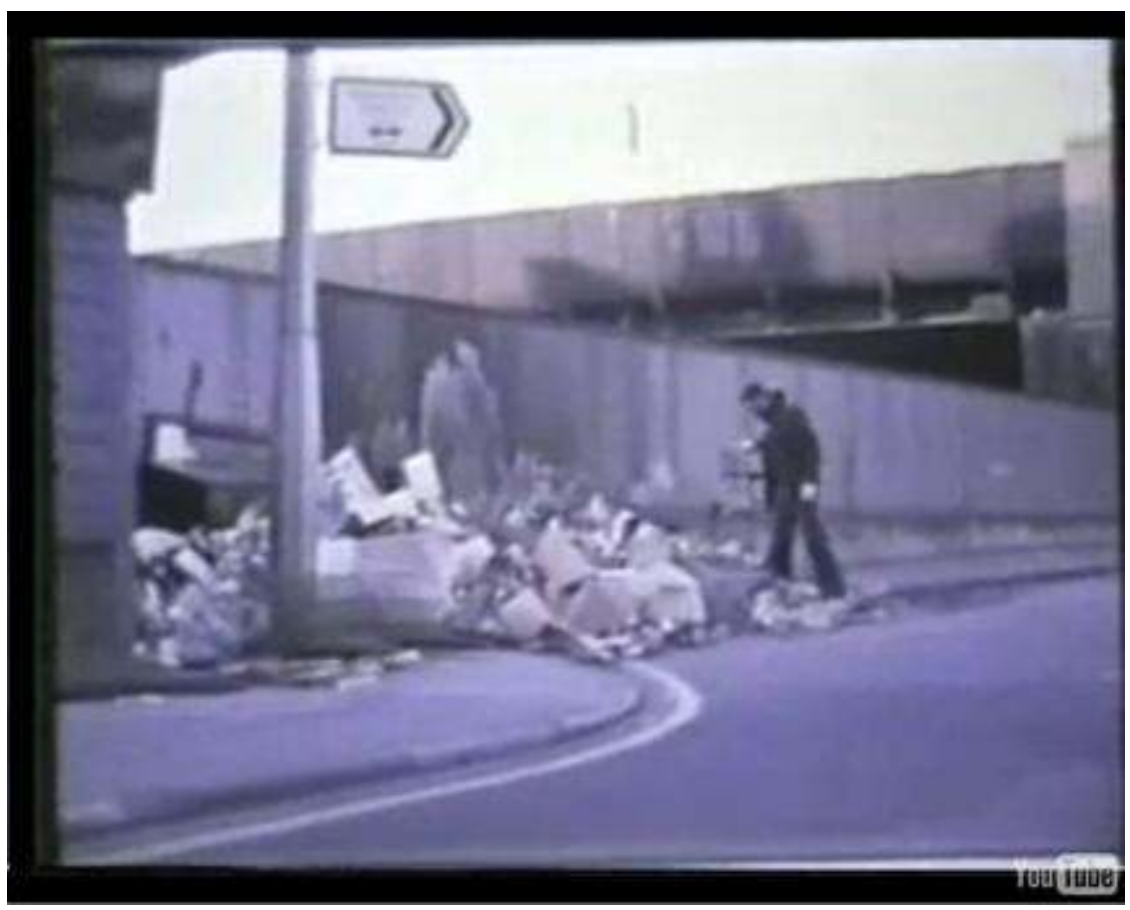


Figura 20. Víctor Muñóz, "Paisaje obsceno"

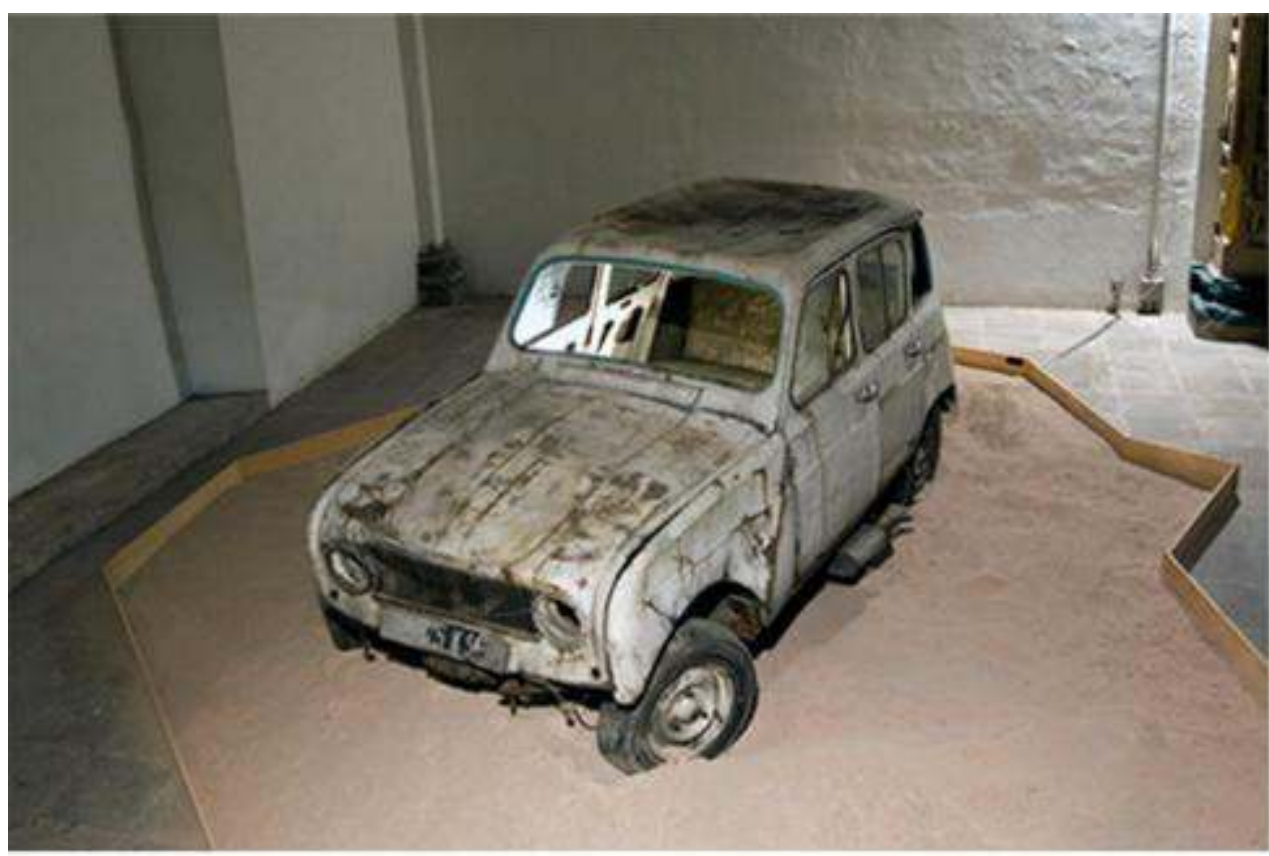

El irlandès Alastair MacLennan (1943), miembro del grupo Black Market International, varias veces presente en México, es uno de los artistas de potencial propositivo y de despliegue conceptual y estético más intensos en nuestros días. Él se integra y se confunde con la basura en performances-instalaciones de apariencia bordoxochiaquense, pero a diferencia de los habitantes del Bordo, y de igual manera en el caso de los cinco creadores anteriores, su caso es el de un performer y antiguo pintor que se sumerge en la basura maloliente y plena de gérmenes como acto de resistencia política estética fina e invisiblemente estallante en combinación con una actitud contemplativa de larga duración (sus performances pueden durar hasta ocho o diez horas). Uno de sus performance-instalación en Belfast (2006) (fig. 21) lo demuestra, pues junto a las instalaciones de Donna Conlon y Helen Escobedo (1934-2010), es tal vez el artista irlandès que, propiciando una magia al mismo tiempo integradora y diferenciadora de las significaciones emergentes de sus obras, va apropiándose de los materiales y generando un espacio poético que renueva el potencial de nuestra sinestesia. 
Figura 21. Alastair MacLennan, gran instalación con basura

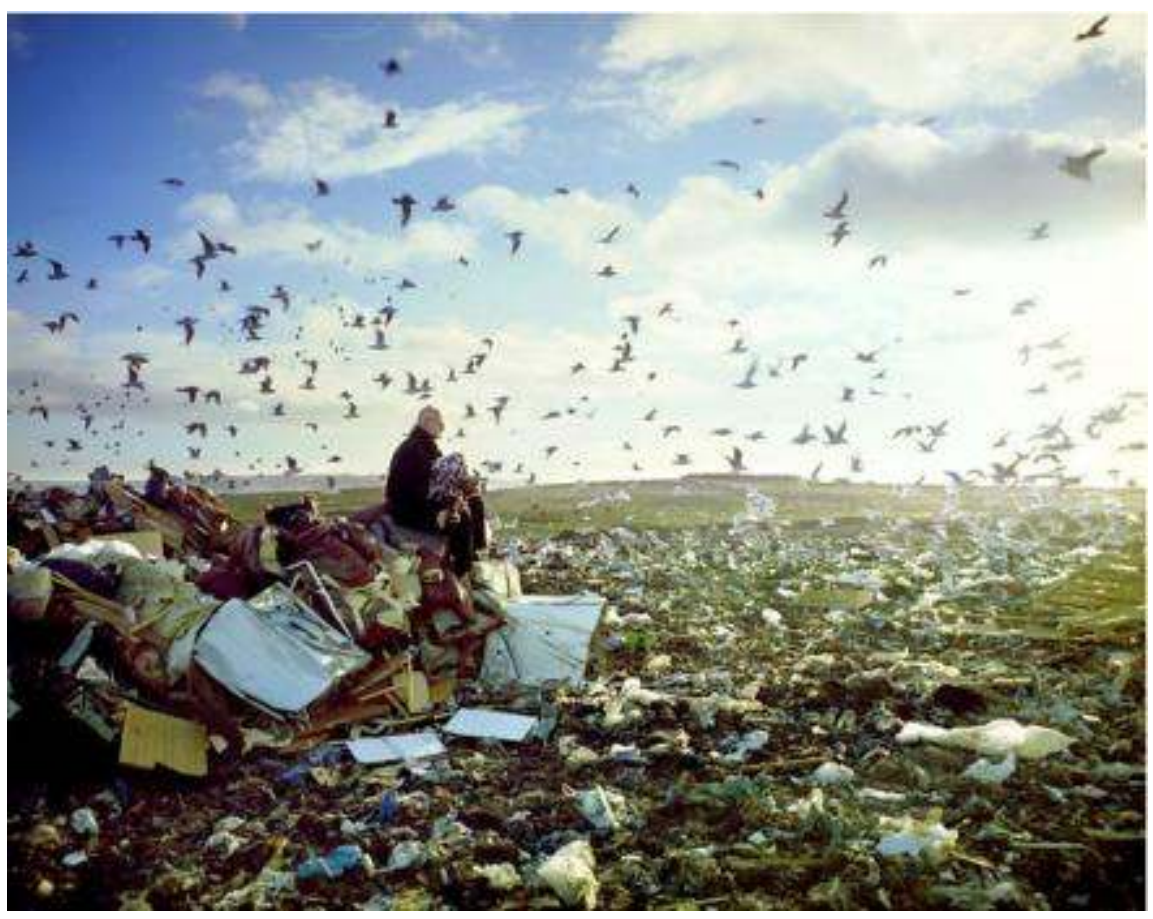

Helen Escobedo realizó obras que podrían considerarse, metafóricamente, como "pequeños Bordos de Xochiaca", emulaciones del gran vertedero en varias instalaciones de su autoría. En Basura reciclada, de 1990 (fig. 22), intimiza la parafernalia de los botescarrito cilíndricos en donde los empleados recolectores de basura en las diversas zonas del Distrito Federal (no habitantes del Bordo) vierten los deshechos. Son conocidos, asimismo, los caminos de basura sinuosos que configuró como instalaciones en el Bosque de Chapultepec, o el espléndido Éxodo (fig. 23), última de sus esculto-instalaciones, expuesta en la explanada del Faro de Oriente durante varios meses del 2010, en donde cuestiona los entresijos injustos de la migración y, por tanto, la dureza del nomadismo político, con sentido trágico. Brillante artista conceptual por su forma de relacionar los objetos e implementos y lanzar un decir crítico contundente, logra conmover nuestra receptividad e involucrarnos en un universo basural de gran calidez, en el caso de Éxodo con base en muñecos de tamaño natural, fabricados con retazos de tela, alambre y botes de pintura vacíos, de diecinueve litros o de un galón. Escobedo siempre tuvo el atino de emplazar sus obras en sitios muy asistidos o transitados de la megalópolis que es el Distrito Federal; nos precipitó al acto críticosensible en el contexto de un elaborado y fino cuestionamiento político. 
Figura 22. Helen Escobedo, "Basura reciclada"

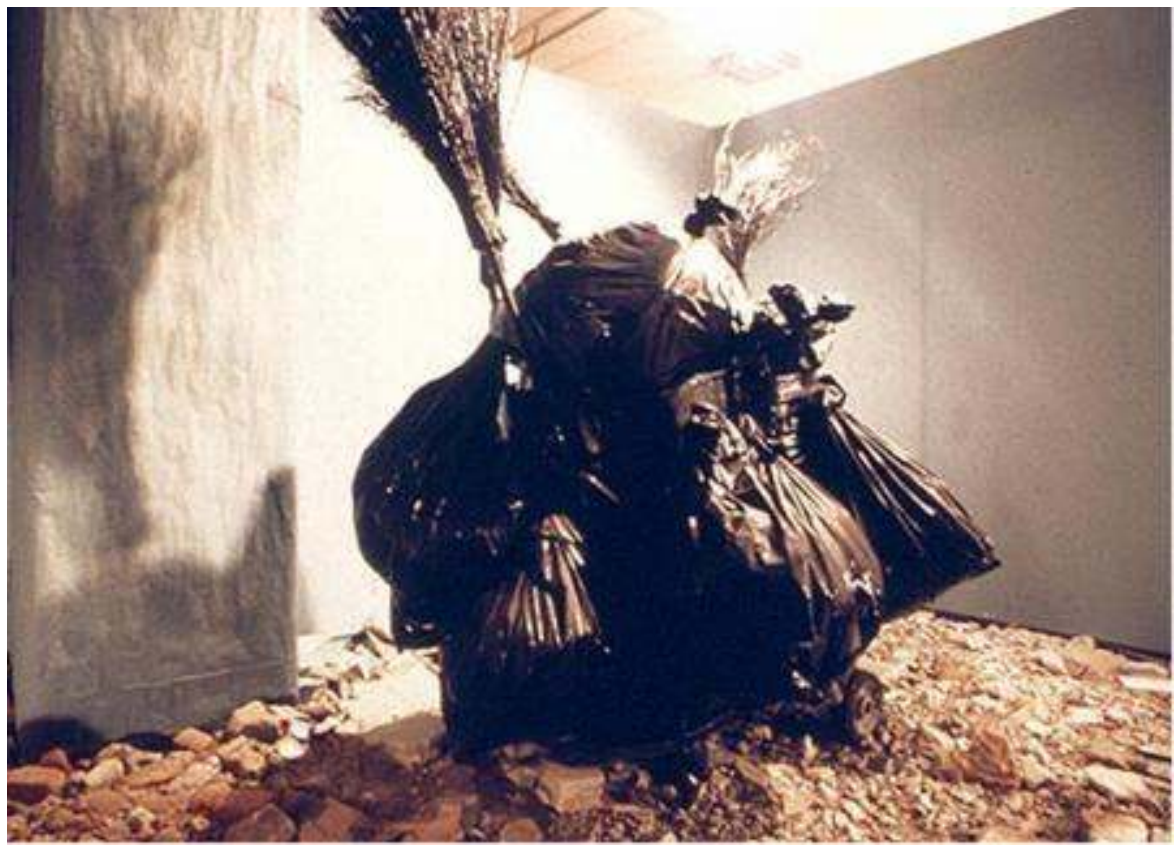

Figura 23. Helen Escobedo, "Éxodo"

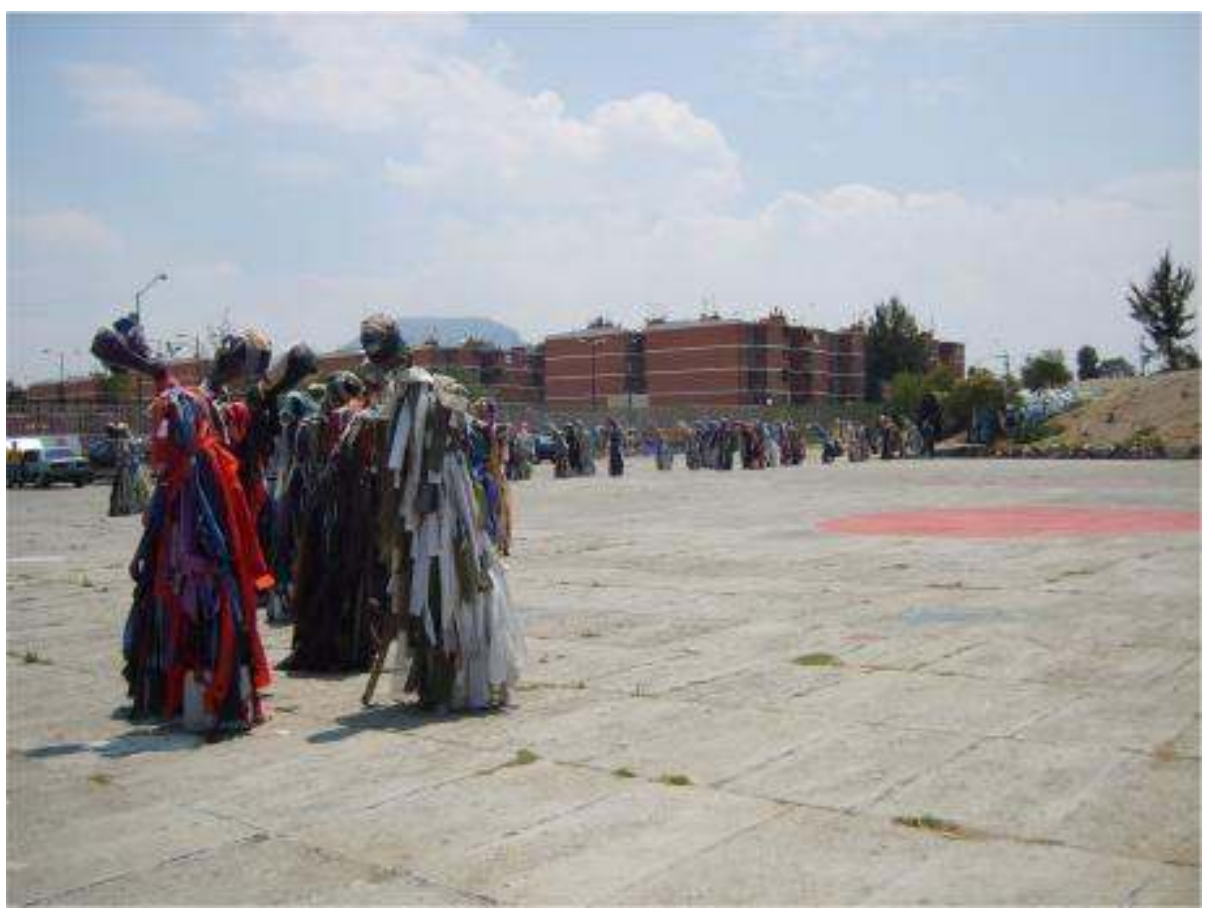

\section{Conclusión}

En este breve artículo he presentado una primera revisión, balance y sentimiento de los usos y resignificaciones artísticos y vivenciales de ese vertedero único, el Bordo de Xochiaca, "retrato" colectivo desde el deshecho y, desde la propia historia del arte, una informe naturaleza muerta-instalación colectiva que todos, en varias generaciones, 
fuimos agrandando a lo largo de setenta años. En su extensa horizontalidad ferozmente pestilente, hoy clausurada, yacimos metafóricamente a través de las materias orgánicas e inorgánicas cotidianas que se volcaron y clasificaron en su suelo. Fue un símbolo de vida y muerte biológica y politicamente hablando; universo de galaxias bacterianas en sus transformaciones y sitio de supervivencia y descontento social de parte de los pepenadores, nunca comprendidos por las autoridades en el poder como seres humanos con una cultura propia desde su origen al año 2010.

Las obras de las que me he ocupado en estas páginas, son formas de atracción hacia el conocimiento nacional y postnacional de los habitantes del Bordo y de nosotros mismos como seres que oscilan entre ser animales de deshechos o ser poseedores de una psique que nos permite las más complejas prácticas ético-estéticas.

El Bordo nos clamó como seres urbanos en proceso desde lo individual a lo fallidonacional y social dentro de un proceso mayor, en la conmoción artístico-política que experimentamos al analizar fragmentos de las obras cinematográficas y las de los artistas conceptuales y de arte de acción de los que abordamos algunos ejemplos resignificantes y reiventores del potencial visual y multisimbólico del Bordo como totalidad humana y de la basura propiamente dicha.

Mientras nuestra urbe se rehace sin cesar, claudica, se extingue, se convierte en referencia de lo humano entre la sensación de lo infinitamente pequeño y lo infinitamente grande frente a la historia y el poder, el Bordo permanecerá en la memoria de quienes vivimos su escatología sublime in situ, al tomar fotografías de sus diversas secciones y hablar con sus habitantes.

Desde el cuerpo y el pensamiento crítico abiertos en su sensibilidad al máximo procesando lo visible, lo no visible, lo tecnológico como estímulo y devastación, el Bordo de Xochiaca, vertedero colosal, fue caos y orden cuyo potencial activador de los sentidos, desbordante imagen bio-social que bien puede ser imaginada cual noche estrellada de absoluta y misteriosa presencia. Seguramente va a perdurar en la memoria de nuestra cultura urbana y el reflejo de sus desigualdades.

41 El Bordo de Xochiaca, lugar de muchas vidas y muertes, nos prodigó tal fuerza en su autonomía y su emplazamiento estepario, que ni la vida urbana en su fluir desarticulado ni la historia del arte, ni el arte mismo, podían haberlo ignorado como imagen colectiva gigantesca, de brutal significación socio-política.

Cual si fuese un homenaje a su recuerdo, el mítico vertedero ha pasado a formar parte de una historia del arte actual a través de la decisión de declararlo una de las naturalezas muertas-instalación más impactantes de la megalópolis, otorgando nuevo oxígeno al fascinante género pictórico de la naturaleza muerta y a mi estatus de historiadora del arte. 


\section{BIBLIOGRAFÍA}

AGUSTíN, José, La contracultura en México. La historia y el significado de los rebeldes sin causa, los jipitecas, los punks y las bandas, México, Grijalbo, 1996, ils.

GARCÍA Ponce, Juan,Crónica de la Intervención, 2 vols., México, Fondo de Cultura Económica, 1982.

KAPROW, Allan, L'art et la vie confondus, trad. de Jacques Donguy, Paris, Centre Georges Pompidou, 1996, ils.Medina, Cuauhtémoc et alius, La era de la discrepancia (libro-catálogo), México, Universidad Nacional Autónoma de México, MUCA, 2007, ils.

MEDINA, Cuauhtémoc, "Problemas de memoria”, ensayo inédito. [Diagnóstico de la trama socio artística y las políticas culturales en México durante la segunda mitad del siglo XX].

Mosquera, Gerardo, "El arte que va hacia afuera”, en Así está la cosa. Instalación y arte objeto en América Latina (catálogo), México, Fundación Cultural Televisa, Centro Cultural / Arte Contemporáneo, 1997, ils., pp. 22-24.

SCHMIDT-WELLE, Friedhelm (coord.), Multiculturalismo, transculturación, heterogeneidad, poscolonialismo. Hacia una crítica de la interculturalidad, México, 2011.

SCHMIDT, Samuel, Los grandes problemas nacionales. Versión siglo XXI, México, Aguilar, 2003 (Nuevo siglo, $\mathrm{s} / \mathrm{n})$.

ZAMORA AGUILAR, Fernando, Filosofía de la imagen, México, Universidad Nacional Autónoma de México, Escuela Nacional de Artes Plásticas, 2007 (Espiral, s/n).

\section{Filmografía}

Crates

Autor: Alfredo Joskowicz

Formato: largometraje

Actor principal: Leobardo López

Duración: 60 minutos

Lugar: México

Año: 1970

Nadie es inocente

Autora: Sara Minther

Formato: cortometraje-documental

Actores: muchachos no actores de Ciudad Nezahualcóyotl: Rafa Punk Rojas, Pablo El Podrido Hernández, Javier Campos Cienfuegos, Jaime Cebollas, Alejandro Suárez El Pollo, La Lupita, Antonio Calleja.

Duración: 9 minutos

Lugar: México

Año: 1986

Habitáculos

Autora: Gabriela Santos del Olmo

Formato: cortometraje

Actores: amigos y personas que no son actores

Duración: 18 minutos 
Lugar: México

Año: 2005

Pepenadores

Autor: Rogelio Martínez Merling

Formato: largometraje

Actores: habitantes del Bordo de Xochiaca

Duración: 27 minutos

Lugar: México

Año: 1992

\section{NOTAS}

1. Nombre dado a los recolectores de basura en México y América central.

2. A raíz de la creación de las juntas de mejoramiento moral, cívico y material para resolver la falta de servicios en el Oriente de la Ciudad de México, que promovieron la independencia política y administrativa de las colonias, se construyó, en el año 1945, el Bordo de Xochiaca y el túnel de Tequixquiac. Esto propició la afluencia de habitantes, formándose las primeras colonias, entre las que se encuentran: Juárez Pantitlán, México, el Sol y el barrio de Juárez Pantitlán o San Juan en el punto en el que se unen los municipios Chimalhuacán y Nezahualcóyotl, en el oriente de la Ciudad de México. Entre 1946 y 1947, el presidente Manuel Ávila Camacho favoreció a las personas proletarias que integraron la Colonia México. Desde esas fechas en adelante, se realizaron lentamente mejoras a las colonias del Bordo, pero fue durante el período 1959-1963 que el gobernador Gustavo Baz autorizó los fraccionamientos de las colonias Metropolitana, Modelo, Xochitenco, Nezahualcóyotl, San Mateito y Reforma. En 1960, la Federación de Colonos del ex vaso de Texcoco solicitó al gobernador Gustavo Baz su separación del municipio de Chimalhuacán y la creación de un nuevo municipio. Aducían que los 80 mil habitantes aspiraban a tener una vida social y política autónoma. Fue el 20 de febrero de 1963 que el gobernador sometió a la consideración de los diputados de la XLI Legislatura del Estado de México el proyecto de decreto para erigir el municipio de Nezahualcóyotl. La iniciativa fue aprobada el 3 de abril de 1963. A partir de esa fecha, los sucesivos presidentes de México han actualizado la legislación que ha regido tanto la creación de nuevas colonias y todo tipo de servicios, como la administración de los lotes o fragmentos de tierra con propietario y la muy compleja regulación del Bordo de Xochiaca como vertedero.

3. Ver nota i.

4. Los "chavos banda" surgen de una población flotante de jóvenes que crecen en el desequilibrio económico-social de sus familias, ciudades y países en donde predominan economías neoliberales. A veces, en escuelas gubernamentales adquieren una educación primaria y secundaria, lo cual permitiría conseguir un empleo temporal o más o menos permanente, realidad que no alcanzan, debido a que provienen de familias disfuncionales de cuyo seno huyen siendo niños aún o desde la adolescencia, dedicándose al robo, la provocación y, a veces, al asesinato. Cf. Agustín, José, La contracultura en México. La historia y el significado de los rebeldes sin causa, los jipitecas, los punks y las bandas, México, Grijalbo, 1996, ils., pp. 107-111.

5. En la poética del cine de Andrei Tarkovski los objetos tienen una especial importancia. Pueden tejer con su presencia el sentido fundamental de un discurso, o simbolizar el principio o el fin de las etapas de vida de alguno de los personajes. Así, en la película Nostalgia (1986), vemos que algunas botellas y libros aparecen al lado del poeta que es el protagonista; una de esas veces sólo hay algunas botellas de vidrio vacías, bajo la lluvia, y en dos ocasiones más las botellas y los libros 
organizados como naturalezas muertas o bodegones, uno de ellos en llamas, simbolizan el fin psíquico del poeta, quien cae muerto en medio de ruinas, al final de la obra.

6. Joël-Peter Witkin es uno de los fotógrafos más interesantes en la actualidad. Nació el 13 de septiembre de 1939 en Brooklyn, Nueva York. Trabajó como fotógrafo de guerra entre 1961 y 1964, en la Guerra de Vietnam. En 1967 decidió trabajar como fotógrafo freelance y se convirtió en el fotógrafo oficial de City Walls, Inc. Después estudió escultura en la Cooper School of Fine Arts de Brooklyn y en 1974 y luego en la Universidad de Nuevo México, en Albuquerque. Su artista favorito y gran influencia es el Giotto. Sus fotos suelen involucrar temas y cosas tales como muerte, sexo, cadáveres (o partes de ellos) y personas marginales como enanos, transexuales, hermafroditas o gente con deformaciones físicas. Sus complejas fotografías a menudo evocan pasajes bíblicos o pinturas famosas. Su acercamiento al proceso físico de la fotografía es altamente intuitivo, incluye manchar o rayar el negativo e imprimir con las manos.

7. Véase obra de Roe Ethridge y otros fotógrafos que trabajan conceptos novísimos de la naturaleza muerta y el bodegón en su fotografía, en la revista Vice, México, julio de 2010.

8. El actor que representó a Crates fue el cineasta Leobardo López, autor de El grito, documental que sintetiza con sensible objetividad los hechos del 68. López, quien se suicidó después del término de la obra de Joskowickz, fue amigo de éste.

9. Al hablar de "saberes" de la pobreza, doy un sentido paulofreiriano al concepto. Es decir, contrariamente al desdoro en que se enmarca a la pobreza, entiendo que no hay una sino muchas pobrezas y cada una posee su operatividad y especificidades en el flanco doloroso que la generación de la cultura posee inevitablemnte en el mundo capitalista. Freire, pedagogo brasileño, propuso que la educación no debía ser impositiva sino estimulante del potencial máximo del educando, llevándolo a valorar y desarrollar sus propios recursos.

10. Tanto el nezense que se despide del municipio, como su amigo, el "otro"protagonista que cruza el Bordo al viento, se parecen al "taimado", personaje que para sobrevivir necesita ser astuto, hipócrita, ya que está desprovisto de medidas para vivir, siquiera, con lo básico. El taimado se siente ínfimo, pero permanece en ese estado, sin escalada alguna, resolviendo su vida en un presente inmediato.

11. En su versión mexicana, el "valemadrismo" es una actitud, antes que solamente un concepto. Proviene, por un lado, de la impotencia de resolución de una situación, problema, concepto u otra instancia en el presente de quien lo experimenta y, por el otro, de una postura -de origen socio-histórico- resuelta en sesgo frente a la complejidad del pensamiento mestizo en cuyo fondo pervive la potencia de una fuerte pluralidad cultural y política, pero también la imposición, amada y odiada de la figura femenina, en este caso la figura de la madre (por ejemplo: Coatlicue, la constitución de la Patria -en realidad "matria"-, para el caso mexicano), la mujer sumisa, la mujer empoderada de hoy y suma y sigue. El valemadrismo es casi una aporía, una cerrada paradoja conductual en acción y guarda cierta analogía histórico social con aquel concepto utilizado por los dadaístas en el Cabaret Voltaire: le je m'en foutisme, con el cual atacaban tanto al arte occidental en su totalidad, como a la burguesía de su tiempo, aunque aparentemente éste no tenga la raigambre paradójica frente a lo femenino que el otro contiene. Su origen comienza, quizá, con el dandismo decimonónico.

12. Juan García Ponce, Crónica de la Intervención, México, Fondo de Cultura Económica, 1982, vol. 2, p. 1428. Citado por Cuauhtémoc Medina en "Problemas de memoria", texto inédito en donde el crítico hace un diagnóstico de la trama socio artística y la política cultural en México durante la segunda mitad del siglo XX. Agradezco a Medina el haberme facilitado su agudo texto. 


\title{
RESÚMENES
}

Este ensayo busca hacer tambalear una vez más el corpus conceptual y "las maneras de ver" de la historia del arte enfrentándola al caso espléndido del Bordo de Xochiaca, el enorme vertedero de basura en el lado occidental de la Ciudad de México a donde, además, llegan aguas negras. Así, en tanto que historiadora del arte, he declarado al Bordo de Xochiaca la naturaleza muertainstalación más grande imaginable en mi ciudad, ya que está hecha, día con día, por todos los que vivimos en ella. Al llevar a cabo esta especie de decreto conceptual y estético, surge una epistemología en la cual la naturaleza muerta se enriquece en tanto que género pictórico antiquísimo. Se convierte, por así decir, en una instalación que provoca una especie de correspondencia, una transubstanciación de las artes y de las realidades visual-espaciales urbanas, mas también juega un papel de doble resistencia, es decir, amar la reintegración de niveles diversos de la vida y crear una estética en incesante movimiento. Otra dimensión que aborda este ensayo es la inclusión crítica que hacen algunos artistas mexicanos e internacionales de la basura en sus obras.

Il s'agit de faire basculer une fois de plus le corpus conceptuel et «les manières de voir » de l'histoire de l'art en les confrontant à l'extraordinaire cas du «Bordo de Xochiaca ", ancien dépotoir où sont déversées les poubelles et où s'écoulent les égouts de la partie occidentale de la ville de Mexico. En tant qu'historienne de l'art, je déclare que le Bordo de Xochiaca est l'installation-nature morte la plus grande que l'on puisse imaginer à Mexico puisqu'elle est réalisée jour après jour et indirectement par nous tous. A partir de cette prémisse conceptuelle et esthétique, on peut dégager une épistémologie dans laquelle la nature morte s'enrichit en tant que genre pictural ancien. Elle se déplace, pour ainsi dire, vers une installation provoquant, d'abord une sorte de correspondance et de transubstantiation des arts et des réalités visuellesspatiales urbaines, mais joue aussi un rôle de double résistance: aimer la réintégration des divers niveaux de la vie et créer une esthétique en mouvement. Une deuxième dimension de cet essai est l'utilisation, par quelques artistes mexicains et internationaux, des déchets dans leurs œuvres.

\section{ÍNDICE}

Palabras claves: creación urbana, vertedero, basura, epistemología estético-política, creación y ética en el historiador del arte, siglo XX

\author{
AUTOR \\ ELIA ESPINOSA \\ Historiadora del arte, Investigadora del Instituto de Investigaciones Estéticas - Universidad \\ Nacional Autónoma de México
}

